\title{
Interpreting soil and topographic properties to conceptualise hillslope hydrology
}

\author{
J.L. Ticehurst ${ }^{\text {a,b,c,*, }}$, H.P. Cresswell ${ }^{\text {c }}$, N.J. McKenzie ${ }^{c}$, M.R. Glover ${ }^{c}$ \\ ${ }^{a}$ Integrated Catchment Assessment and Management Centre, Australian National University, ACT, 0200, Australia \\ ${ }^{\mathrm{b}}$ Centre for Resource and Environmental Studies, Australian National University, ACT, 0200, Australia \\ ${ }^{\mathrm{c}}$ CSIRO Land and Water, Butler Laboratory, G.P.O. Box 1666, Canberra, ACT, 2601, Australia
}

Received 14 March 2005; received in revised form 23 June 2006; accepted 27 June 2006

Available online 25 September 2006

\begin{abstract}
The sustainability of agricultural practices is enhanced when vegetation makes optimal use of natural hydrological processes. For example, planting tree belts where slope gradient sharply decreases can enable harvesting of run-on water. This can be beneficial for example in reducing water logging and enhancing tree production. There is a need for rapid and low cost identification of water flow paths and conceptualisation of hillslope hydrology so that local landuse planning can reflect such opportunities. The collection of detailed hillslope hydrological data is prohibitively expensive for such applications and so the use of soil morphology and visual observation of topography and surface condition is evaluated as an alternative.

At a study site in south eastern Australia the soil physical profile was described down a hillslope with additional measurements of the hydraulic conductivity, bulk density, cation exchange capacity, electrical conductivity, and particle size distribution of the key horizons. This data was used to identify the perceived significant hydrological flow paths down the hillslope. Measurement of the surface runoff, subsurface lateral flow, and the distribution of saturation measured in piezometers were subsequently used to test the conceptual hydrological model.

Soil morphology, particularly the soil colour and presence of redox concretions were useful in identifying the locations and depths where saturation and lateral flow occur. The morphology provides an integrated reflection of the dominant hydrological conditions, but care must be taken to ensure that the observations reflect the current hydrological environment and not relic conditions. Other collaborating information such as the history of geomorphological events at the site, a validation of plausible water sources for the potentially transmitting layers, surface soil condition and landholder observations give improved confidence. Combining soil morphological understanding with visual observations of other site characteristics enabled rapid conceptualisation of hillslope hydrological behaviour as needed for local landuse planning.
\end{abstract}

(C) 2006 Elsevier B.V. All rights reserved.

Keywords: Hillslope hydrology; Lateral flow; Oxidation-reduction; Soil morphology

\section{Introduction}

Knowledge of water movement and accumulation through the landscape is becoming increasingly important to the sustainability of Australia's agricultural systems. Waterlogging and salinity, caused by the accumulation of excess water not used by the annual, shallow rooting vegetation are evident in some locations (Dunin et al., 1999). Conversely changes in the regional climate have made severe drought conditions possible during moderate El Niño events (Suppiah, 2004), increasing risk of crop failure, tree mortality and insufficient pasture growth to support livestock. Vegetation pat-

\footnotetext{
* Corresponding author. Integrated Catchment Assessment and Management Centre, Australian National University, ACT, 0200, Australia.

E-mail address: Jenifer.Ticehurst@anu.edu.au (J.L. Ticehurst).
}

terns need to make optimal use of the natural landscape hydrology. For example, targeted perennial vegetation, such as tree belts oriented across-slope, have the potential to harvest and use excess water running from higher ground. Such a strategy might result in benefits from reduced waterlogging and salinity in wet periods, and less drought-induced tree mortality in dry periods.

Implicit in the identification of suitable locations in the landscape for a given landuse is knowledge of local hydrological processes. Conceptual models of hillslope hydrology, including lateral water flow paths, are required to support landuse planning decisions. However, field-based interpretation of hillslope hydrology needs to be relatively fast and inexpensive if it is to be used for targeting particular landuse options by farmers in this way.

Ideally, a conceptual model of the hydrological function of a hillslope would be developed using measurements of the surface 
and subsurface lateral flow, watertable fluctuations, and change in soil water content. However, such an approach is obviously expensive, time consuming and largely dependant on the weather conditions, particularly rainfall being 'typical' during the period of observation. Numerical modelling can provide more quantitative insight into hydrological processes, but this is not free of expense as the data requirements to run such models still require field measurements, and a conceptualisation of hillslope water flow pathways is a necessary precursor. Modelling is only likely to find application in the planning of large, high-value landuse change. Both the direct measurement of hydrological processes and simulation modelling are well outside the reach of the average Australian farmer planning landuse change on his or her property.

Soil morphological interpretation has been used, for example by Fritsch and Fitzpatrick (1994), to construct soil-waterlandscape models. Given that lateral flow within a soil is most significant through the saturated parts of the profile (Weyman, 1973; Anderson and Burt, 1978; Hurley and Pantelis, 1985), and water is the main factor influencing soil development in most environments (Wysocki et al., 2000), soil water movement can be reflected by the redistribution of soluble compounds. For example trends in the electrical conductivity (EC) (e.g. Seelig and Richardson, 1994) or cation exchange capacity (CEC) (Duchaufour, 1982; Fritsch and Fitzpatrick, 1994) reflect salt concentrations and thus areas of water transmission and accumulation. Soil colour (e.g. Simonson and Boersma, 1972; Khan and Fenton, 1994), mottling (Dunne et al., 1975; Fritsch and Fitzpatrick, 1994) and redoximorphic features, such as iron and manganese concretions, can indicate poor drainage conditions, periodic saturation and leaching (Stace et al., 1968; Khan and Fenton, 1994). It has also been observed that an increase in the amount and size of mottles and concretions correlates to an increase in the duration of saturation (Simonson and Boersma, 1972; Khan and Fenton, 1994). Soil horizons with a massive structure and light texture has been identified as ones that readily transmit water (Duchaufour, 1982; Novak, 1994; Fritsch and Fitzpatrick, 1994), because the water movement removes the iron $(\mathrm{Fe})$, degrades the soil structure and initiates clay eluviation to deeper horizons. Water movement through these horizons is even more likely where there is strong texture contrast between the conducting layer and the horizon below.

However, care must be taken when interpreting soil properties to indicate the hydrological environment. For example, $\mathrm{Fe}$ can be fixed by humic material, and therefore unavailable to precipitate into concretions, so the redoximorphic features may not reflect the water conditions (Duchaufour, 1982; Novak, 1994). Conversely, some organic matter is required to provide the energy for the bacteria to reduce the Fe (Fitzpatrick, 1988) so an environment too low in organic matter would not be able to reduce and mobilise the Fe. There can also be a lag period between the current hydrological environment and the observed soil properties (e.g. Cox et al., 1996).

This research tests the hypothesis that soil morphology can be used to identify significant lateral flow paths for water at a field site and thus can be integral to the development of low cost conceptual models of local scale hydrology. Soil properties, and observations of topography and surface condition, are used to construct a conceptual hydrological model for a hillslope in south eastern Australia. The model is tested using hydrological measurements at the site. The approach is evaluated in terms of its applicability for assessing specific locations for planting tree belts to harvest run-on water.

\section{Materials and methods}

\subsection{Study area}

The study area for this research covers 42.8 ha, located in southern New South Wales, Australia, centered at $35^{\circ} 49^{\prime} 41^{\prime \prime} \mathrm{S}$, $146^{\circ} 21^{\prime} 27^{\prime \prime} \mathrm{E}$ (GDA 94) (Fig. 1). It is in the Billabong Creek catchment, which is subject to waterlogging and salinity (Baker et al., 2001). The site is typical of other steep granite derived hillslopes in south-east Australia. It was subject to deposition of aeolian material throughout the Pleistocene (Walker et al., 1988). The aeolian mantle once coating the upper slopes has
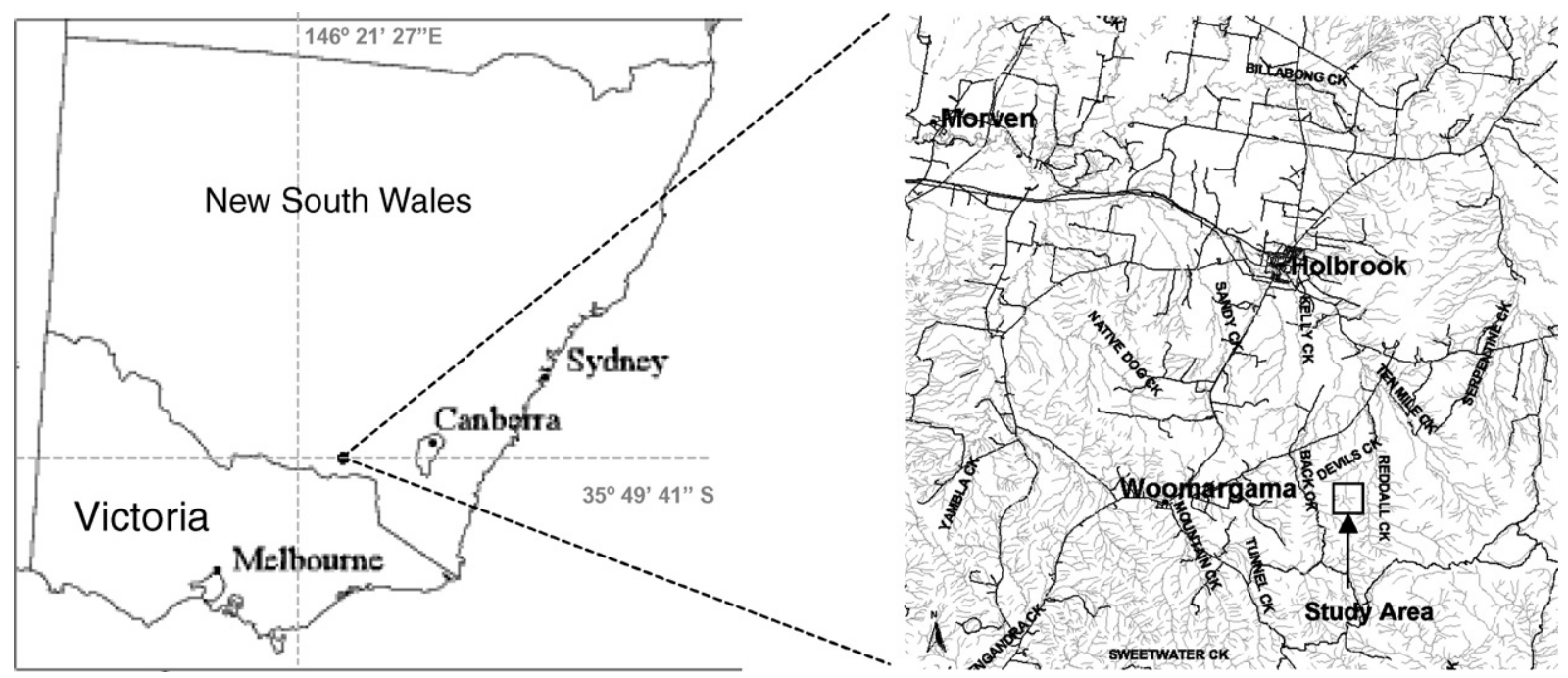

Fig. 1. Location of field study area in southern New South Wales, Australia. The right hand inset shows the major creeks (grey lines) and roads (black lines). 
subsequently been stripped by erosion including a series of colluvial landslips, creating overlapping fans down the hillslope. A distinct topographic break-of-slope exists, below which the colluvial fans grade down to the lower slopes.

The soils at the site form a soil catena from Brown, to Yellow then Grey Chromosols, with Grey and Black Sodosols at the bottom of the hillslope (nomenclature follows Isbell, 2002). Buried soils were identified at the site by the presence of a horizon below the B2 horizon with colour and a lighter texture resembling an A2 horizon. It was assumed that this horizon was a buried A 2 horizon and the horizons below it were also buried. The buried horizons were evident on all but the upperslopes and were likely to have formed from colluvial landslips. The soil properties are discussed in more detail in Section 3.1.

The study catchment has been cleared for grazing, with original clearing occurring in the region in the late 1880's (Holbrook Landcare Group, pers. comm.). The pasture mainly consists of annual species including Lolium multiflorum (Ryegrass) and Echium plantagineum (Paterson's Curse), with scattered native perennial grasses such as Themeda triandra (Kangaroo Grass).

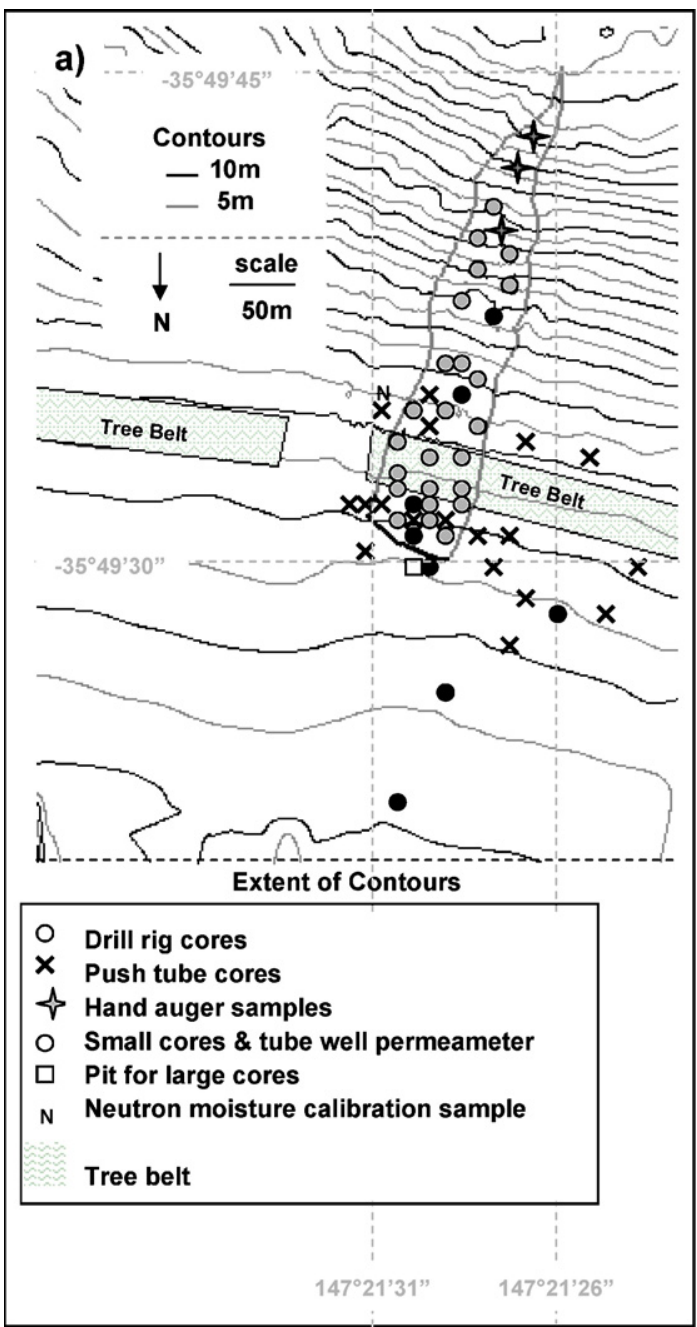

There is a wide interest in conservation tree planting and farm forestry in the study region. An established tree belt of Eucalyptus saligna (Sydney Blue Gum) and Acacia melanoxylon (Blackwood) species cover 4 ha of the study area (Fig. 2). The landowner planted the tree belt 7 years before the commencement of this study to treat severe waterlogging on the lower slopes. He had not noticed any notable change in the hydrology at the site, but found it hard to compare given the variation in rainfall.

\subsection{Methods for topographic and soil description}

The site was surveyed with a global positioning system to generate a digital elevation model. The survey was made taking measurements at $5 \mathrm{~m}$, or $5 \mathrm{~s}$, which ever took longest, along transects that were approximately $5 \mathrm{~m}$ apart across the slope. Additional measurements were taken across ridges, drainage lines and the catchment boundaries. The output DEM was plotted to a resolution of $2 \mathrm{~m}$, and was also used to develop contours at $10 \mathrm{~m}, 5 \mathrm{~m}$ and $2 \mathrm{~m}$ intervals. Further details about the DEM are given by Ticehurst (2004). The catchment boundary

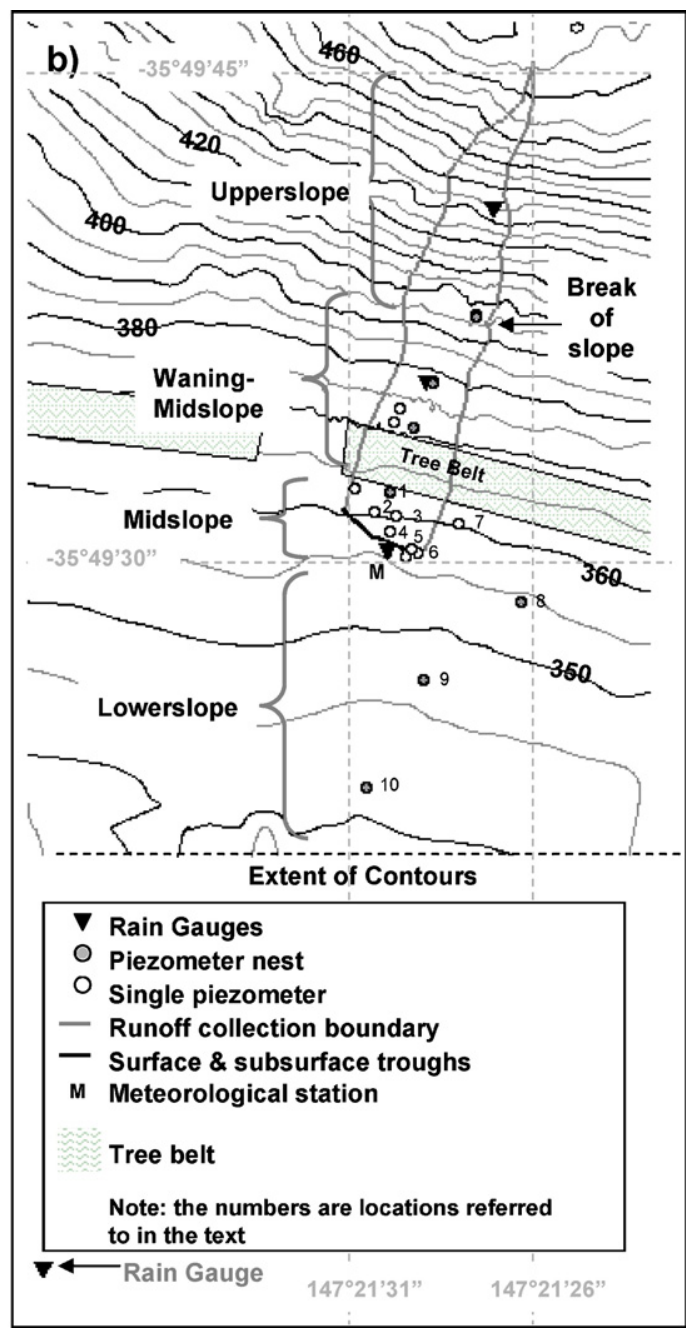

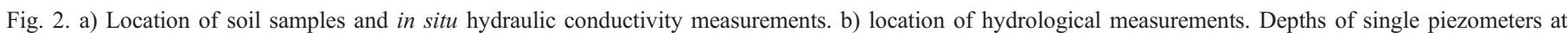
locations $3,5,6$ and $7 \approx 0.5 \mathrm{~m}$, location $2 \approx 2 \mathrm{~m}$, and location $4 \approx 6 \mathrm{~m}$ or bedrock. Catchment area $=2.9$ ha. Adapted from Ticehurst et al. (2005). 
was estimated using the GPS information and then groundtruthed by field inspection and remeasured with the GPS. Eight continuous intact soil cores were taken in aluminium tubing down to bedrock or to a maximum depth of $16 \mathrm{~m}$, using a drill rig. The location of the samples is shown in Fig. 2a. Eighteen push tube samples were taken down to $2 \mathrm{~m}$ depths at locations also shown in Fig. 2a. When it was not practical to take samples with the drill rig or push tube, due to the steep slopes and rocky outcrop, samples were augered by hand. All of the soil profile samples were described using McDonald et al. (1990) and classified according to the Australian Soil Classification (Isbell, 2002). This included a visual identification and estimate of the abundance of ferruginous (iron) and manganiferous (manganese) segregations, which were distinguished by colour (red and black respectively).

Twenty-four small, undisturbed core samples $(9.7 \mathrm{~cm}$ diameter, $7.5 \mathrm{~cm}$ deep) were taken from the A2 horizon across and down the hillslope (Fig. 2a), using the sampling technique given in McKenzie and Cresswell (2002). In addition five small cores were taken using the same method from each of $10 \mathrm{~cm}$, $20 \mathrm{~cm}, 30 \mathrm{~cm}, 40 \mathrm{~cm}, 50 \mathrm{~cm}, 60 \mathrm{~cm}, 80 \mathrm{~cm}$ and $100 \mathrm{~cm}$ depths for calibration of a neutron moisture meter. The neutron moisture meter data is not presented in this paper but the core samples were used for soil characterization. Twelve large soil cores ( $25 \mathrm{~cm}$ diameter, $20 \mathrm{~cm}$ deep) were collected as described by McKenzie and Jacquier (1996). A pit was excavated with a backhoe at the bottom of the runoff collection area (Fig. 2a) in order to collect the samples. Four cores were taken from each of the A2, upper B2 and lower B2 horizons.

Vertical saturated and unsaturated hydraulic conductivities were measured on both the small and large cores. A modification of the constant head permeameter method described by McIntyre and Loveday (1974a) was used to determine the saturated hydraulic conductivity of the small core samples. The key variation in the method was that the intact soil cores were used instead of sieving and repacking the soil. Saturated hydraulic conductivity was measured on each of the large cores according to the method of McKenzie and Jacquier (1996). Unsaturated hydraulic conductivity was determined at $30 \mathrm{~mm}$ suction using a mini infiltrometer on the small cores (McKenzie et al., 2002: method 510.05) and at $10 \mathrm{~mm}$ suction on the large cores (McKenzie et al., 2002). Horizontal hydraulic conductivity may vary significantly from vertical conductivity in some soils (e.g. Ritsema et al., 1996). This would be of greatest concern in a study of lateral flow such as this one if the horizontal conductivity were significantly less than the vertical. This type of anisotropy would be most likely in soils with a low porosity, fine texture and evidence of vertical structures that may enhance vertical and impede lateral flow, such conditions are not evident in the soils at this site.

Bulk density was determined on the small cores, on subsamples from the large cores and on the small cores collected for the neutron moisture meter calibrations following the methods from Cresswell and Hamilton (2002). Particle size distribution (PSD) was determined for eight of the key horizons at several locations down the hillslope using the method described by Hutka (1994).

A 1:5 soil water extract was used to determine the $\mathrm{pH}$ (Rayment and Higginson, 1992a) and EC (Rayment and
Higginson, 1992b) for the key soil horizons of the field site. The EC and CEC were determined using a $1 \mathrm{M}$ ammonium chloride extracting solution at $\mathrm{pH} 7.0$ with a pre-treatment for soluble salts (CEC method 15A2 in Rayment and Higginson, 1992c). CEC can vary depending on the amount of clay and organic matter present (Birkeland, 1984), so in order to be able to compare the CEC of different horizons accounting for the difference in clay the CEC was expressed as $\mathrm{cmol}(+) / \mathrm{kg}$ of clay. Isbell et al. (1997: 15) comment that this method "enables comparison across soils of differing clay contents, and to some extent can serve as a comparative indication of clay mineralogy in soils of similar clay contents, thus giving a better indication of leaching and weathering stage". Experience in the district suggests that the organic carbon is very small in both the B horizon and deeper horizons (as low as $<0.2 \%$ ) so it was considered that the method was suitable for all but the surface horizon at this site.

Exchangeable sodium percentage (ESP) was calculated as exchangeable sodium divided by CEC and expressed as a percentage. An ESP of $6 \%$ is defined as a threshold above which soil stability rapidly decreases (reviewed in Sumner, 1995). However, if the EC is also high then a soil with a high ESP can remain stable.

\subsection{Methods for hydrological monitoring}

The hydrological behaviour of the study area was monitored from August 2001 until October 2003. A full meteorological station was installed (Fig. 2b) to record the relative humidity and temperature (Vailsala HMP45D sensor), wind speed and direction (Met One Instruments models 024A and 014A), and radiation (Kipp and Zonen CM11 pyranometer). Four Hydrological Services TB3/0.2P tipping bucket rain gauges were installed at the field site, near the top (RT), middle (RM), and bottom (RB) of the hillslope, plus near the Meteorological station (Met) (Fig. 2b). The buckets in the rain gauges had a $0.2 \mathrm{~mm}$ capacity, and were logged at 6 -minute intervals.

Within the study area a 2.9 ha subcatchment (Fig. 2a and b) was intensively monitored. A subsurface trough connected to a tipping bucket measured the volume of subsurface lateral flow (SLF) of water through the A2 horizon. The subsurface trough was constructed following Varcoe et al. (1999). Surface runoff was measured with troughs and a series of Replogle-BosClemmens (RBC) flumes (Clemmens et al., 1984). Initially a flume with a throat width of $0.3 \mathrm{~m}$ was installed to account for measuring runoff from a 1 in 10 year rainfall event. When drought became apparent during the study period a smaller flume (throat width $0.2 \mathrm{~m}$ ) was installed (March 2002) in series below the large flume to measure smaller runoff events more accurately. Both the subsurface and surface troughs were installed across the whole width of the subcatchment, some $74 \mathrm{~m}$.

Piezometer nests were installed at 4 locations in the runoff collection area, and 3 locations further down the hillslope. These were concentrated on the lower half of the slope where saturation was most likely to occur. Each nest consisted of 3 piezometers, installed at the depth of the $\mathrm{A} / \mathrm{B}$ horizon boundary $(\approx 0.5 \mathrm{~m})$, at the lower bound of the $\mathrm{B} 2$ horizon $(\approx 2 \mathrm{~m})$, and on 
top of the bedrock (down to about $6 \mathrm{~m}$ unless bedrock was reached at a shallower depth). The depth of the single piezometers varied between locations, but are given in Fig. 2b. Most piezometers had a Dataflow or Odyssey capacitance probe installed to log the height of the watertable at 6-minute intervals and manual readings of watertable height were also taken during field visits.

\section{Results and discussion}

The soil stratigraphy of the hillslope is presented in Fig. 3. Nine key soil horizons (A1, A2, B2, 2A2, 2B22, 2B23, 2B24, $2 \mathrm{~B} 25$ and $\mathrm{C}$ ) were identified. The 2A2, 2B22, 2B23, 2B24 and 2B25 were horizons buried by the deposition of sediment from upslope colluvial landslips. A thick band of fine material on the lowerslopes, believed to be an aeolian deposit based on its particle size distribution, had developed A1, A2, and B2 horizons.

\subsection{Interpretation of site characteristics and soil properties}

For the discussion of results the hillslope is divided into four geomorphic zones, as shown in Fig. 3. Detailed description by horizon is given in Tables 1, 2, 3 and 4. The soil properties are discussed by horizon, or group of horizons that display hydrological significance as indicated by their colour, degree of leaching and concretions abundance.

\subsubsection{Surface horizon properties}

Surface condition and topography is used here to estimate the significance of surface runoff on the hillslope. The A1 horizon was thin, being $0.12 \mathrm{~m}$ on average, which implies past, and perhaps current, surface erosion on this hillslope. The absence of aeolian material on the upperslopes indicates that surface lateral flow had occurred with associated erosion. In some locations on the upperslope the A1 and even A2 horizons had been eroded completely to leave the B2 horizon exposed at the surface. This is not surprising as the steep elevation gradients (40\%) and high rocky outcrops ( $40 \%$ of the surface) in this hillslope zone is likely to generate a large proportion of surface runoff with significant erosive energy.

There were few distinct and continuous drainage lines down the planar lower hillslope implying that the surface runoff was more of a sheet-flow process than a significant concentration in particular areas.

A break-of-slope exists between the upperslope and the waning-midslope. This change in elevation gradient would increase the likelihood of water infiltrating into the soil and thus decrease the volume of surface runoff. Changes in soil properties of the A2 horizon on the waning-midslope compared to the upperslope, including the lighter colour and increase in redox concretions, indicate that the surface soils are subject to greater saturation. This suggests that concentrated infiltration does occur at the break-of-slope (Table 2).

Poaching of the soil surface by cattle at the boundary from the midslope to lowerslope implies that saturation and waterlogging occurs at that location.

Surface runoff would tend to slow on the lowerslope due to the small topographic gradient (4\%), which increases the likelihood of infiltration. The evidence of oxidation along root channels in the A1 horizon and the light colour, mottles and redox concretions in the A2 horizon, indicates that prolonged saturation is prevalent. Other indications of excess water at the surface in this zone

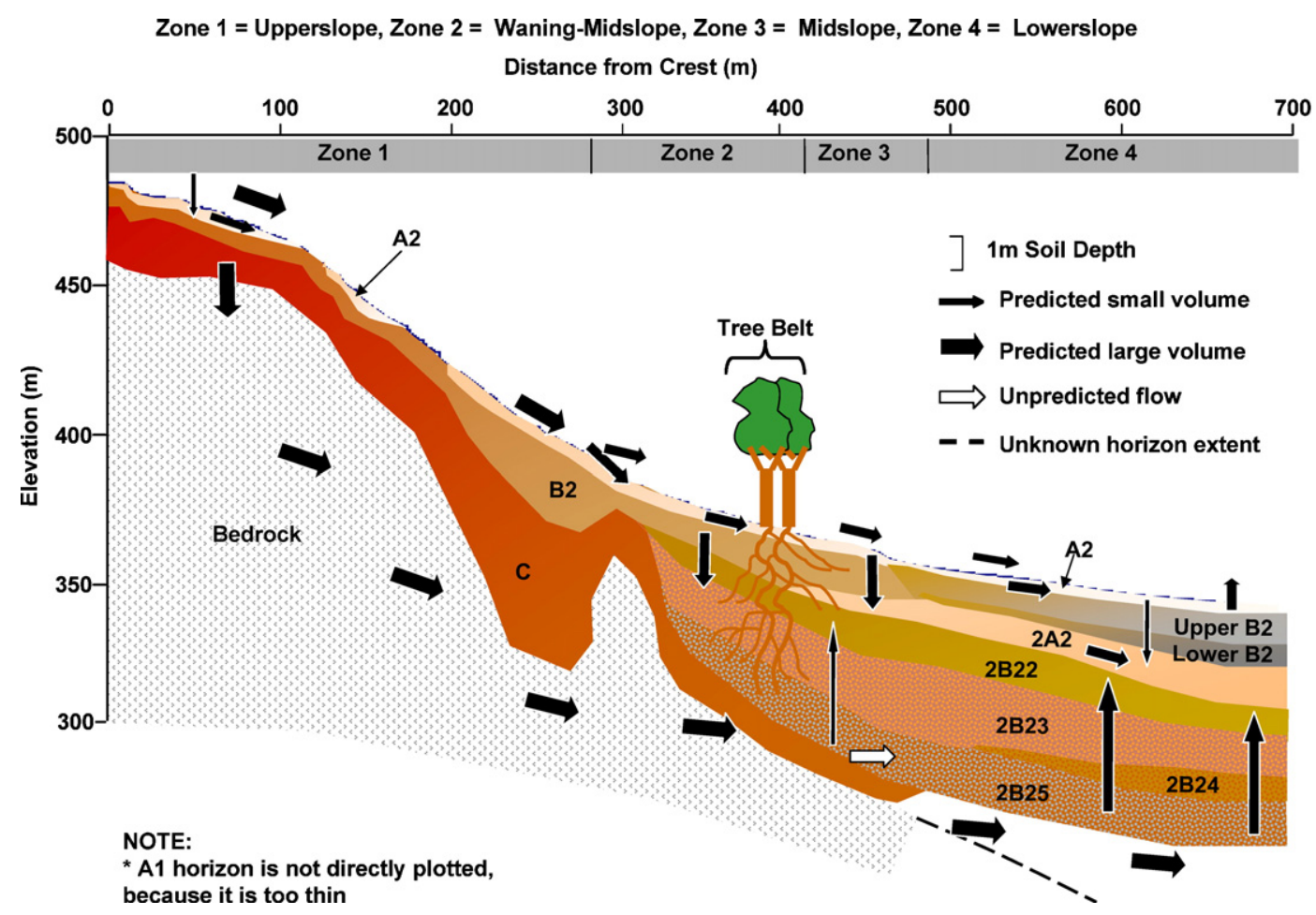

Fig. 3. Soil stratigraphy of the field site and the conceptual hydrological model of the field site based on the interpretation of the topography and soil properties. Adapted from Ticehurst et al. (2005). 
Table 1

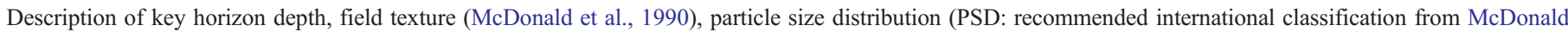
et al., 1990) and structure (McDonald et al., 1990)

\begin{tabular}{|c|c|c|c|c|c|}
\hline Horizon & Property & Upperslope & Waning-midslope & Midslope & Lowerslope \\
\hline \multirow[t]{4}{*}{ A1 } & Depth $^{\mathrm{a}}$ & $0.00-0.05$ to 0.12 & $0.00-0.08$ to 0.21 & $0.00-0.07$ to 0.32 & $0-0.06$ to 0.17 \\
\hline & $\begin{array}{l}\text { Field texture } \\
\left(\mathrm{PSD}^{\mathrm{b}}\right)\end{array}$ & $\begin{array}{l}\text { Sandy loam } \\
(19 \%, 13 \%, 68 \%)\end{array}$ & $\begin{array}{l}\text { Sandy loam } \\
(22 \%, 11 \%, 67 \%) \text { to }(26 \%, 13 \%, 61 \%)\end{array}$ & $\begin{array}{l}\text { Loam to sandy clay loam } \\
(18 \%, 29 \%, 53 \%) \text { to }(33 \%, 16 \%, 52 \%)\end{array}$ & $\begin{array}{l}\text { Loam to sandy clay loam } \\
(34 \%, 35 \%, 31 \%)\end{array}$ \\
\hline & Structure & Massive & Massive & Massive & Massive \\
\hline & Stability & Stable & Stable & Stable & Stable \\
\hline \multirow[t]{4}{*}{$\mathrm{A} 2$} & Depth $^{\mathrm{a}}$ & $0.12-0.20$ to 0.58 & $0.08-0.19$ to 0.53 & $0.09-0.33$ to 0.54 & $0.06-0.27$ to 0.48 \\
\hline & $\begin{array}{l}\text { Field texture } \\
\left(\mathrm{PSD}^{\mathrm{b}}\right)\end{array}$ & $\begin{array}{l}\text { Sandy clay loam } \\
(20 \%, 13 \%, 67 \%) \text { to } \\
(30 \%, 13 \%, 57 \%)\end{array}$ & $\begin{array}{l}\text { Sandy loam to sandy clay loam } \\
(23 \%, 9 \%, 68 \%) \text { to }(23 \%, 13 \%, 64 \%)\end{array}$ & $\begin{array}{l}\text { Sandy loam to sandy clay loam } \\
(29 \%, 16 \%, 55 \%) \text { to }(53 \%, 11,36 \%)\end{array}$ & $\begin{array}{l}\text { Sandy clay loam } \\
(34 \%, 33 \%, 33 \%)\end{array}$ \\
\hline & Structure & Massive & Massive & Massive & Massive \\
\hline & Stability & Slaked & Slaked and dispersed & Slaked and dispersed & Slaked and dispersed \\
\hline \multirow[t]{5}{*}{ B2 } & Depth $^{\mathrm{a}}$ & $0.20-0.80$ to 1.85 & $0.19-0.76$ to 1.70 & $0.33-0.73$ to 1.74 & $0.27-1.20$ to 1.80 \\
\hline & Field texture & $\begin{array}{l}\text { Sandy light to } \\
\text { light medium clay }\end{array}$ & Sandy light to light medium clay & Sandy clay loam to light medium clay & $\begin{array}{l}\text { Light to } \\
\text { medium heavy clay }\end{array}$ \\
\hline & $\left(\mathrm{PSD}^{\mathrm{b}}\right)$ & $\begin{array}{l}(44 \%, 12 \%, 44 \%) \text { to } \\
(30 \%, 13 \%, 57 \%)\end{array}$ & $(26 \%, 10 \%, 64 \%)$ to $(35 \%, 14 \%, 51 \%)$ & $(27 \%, 12 \%, 61 \%)$ to $(33 \%, 12 \%, 55 \%)$ & $(61 \%, 13 \%, 26 \%)$ \\
\hline & Structure & Massive & Weak & Massive to weak & Moderate to strong \\
\hline & Stability & Slaked & Slaked and dispersed & Slaked & Slaked and dispersed \\
\hline \multirow[t]{4}{*}{$2 \mathrm{~A} 2$} & Depth $^{\mathrm{a}}$ & Not present & Not present & $1.36-1.80$ to 1.85 & $1.80-3.15$ \\
\hline & $\begin{array}{l}\text { Field texture } \\
\left(\mathrm{PSD}^{\mathrm{b}}\right)\end{array}$ & & & $\begin{array}{l}\text { Sandy light to light medium clay } \\
(29 \%, 15 \%, 56 \%) \text { to }(31 \%, 14 \%, 55 \%)\end{array}$ & $\begin{array}{l}\text { Sandy clay loam } \\
(29 \%, 11 \%, 60 \%)\end{array}$ \\
\hline & Structure & & & Massive & Grainy \\
\hline & Stability & & & Slaked and dispersed & $\mathrm{N} / \mathrm{A}$ \\
\hline \multirow[t]{5}{*}{$2 \mathrm{~B} 22$} & Depth $^{\mathrm{a}}$ & Not present & $0.76-2.00$ to 2.82 & $1.80-2.80$ to 3.45 & $3.15-3.95$ \\
\hline & Field texture & & Sandy light to light medium clay & Sandy light medium clay & Sandy light clay \\
\hline & $\left(\mathrm{PSD}^{\mathrm{b}}\right)$ & & $\mathrm{N} / \mathrm{A}$ & $(26 \%, 12 \%, 62 \%)$ to $(35 \%, 11 \%, 54 \%)$ & $\mathrm{N} / \mathrm{A}$ \\
\hline & Structure & & Massive & Massive to weak & Weak \\
\hline & Stability & & Slaked and dispersed & Slaked and dispersed & N/A \\
\hline \multirow[t]{4}{*}{$2 \mathrm{~B} 23$} & Depth $^{\mathrm{a}}$ & Not present & $2.00-3.40$ to 3.60 & $2.80-3.45$ to 5.65 & $3.95-5.10$ \\
\hline & $\begin{array}{l}\text { Field texture } \\
\left(\mathrm{PSD}^{\mathrm{b}}\right)\end{array}$ & & $\begin{array}{l}\text { Sandy light to light medium clay } \\
(34 \%, 11 \%, 54 \%) \text { to }(40 \%, 12 \%, 48 \%)\end{array}$ & $\begin{array}{l}\text { Sandy light to light medium clay } \\
(41 \%, 14 \%, 45 \%) \text { to }(47 \%, 12 \%, 41 \%)\end{array}$ & $\begin{array}{l}\text { Sandy light medium clay } \\
(34 \%, 14 \%, 52 \%)\end{array}$ \\
\hline & Structure & & Massive & Massive to weak & Weak \\
\hline & Stability & & Slaked and dispersed & Slaked and dispersed & N/A \\
\hline \multirow[t]{5}{*}{$2 \mathrm{~B} 24$} & Depth $^{\mathrm{a}}$ & Not present & Not present & Not present & $5.10-5.80$ \\
\hline & Field texture & & & & Sandy light clay \\
\hline & $\left(\mathrm{PSD}^{\mathrm{b}}\right)$ & & & & N/A \\
\hline & Structure & & & & Massive \\
\hline & Stability & & & & N/A \\
\hline \multirow[t]{4}{*}{ 2B25 } & Depth $^{\mathrm{a}}$ & Not present & $3.40-4.55$ to 5.50 & $4.70-5.10$ to 6.60 & $5.80-7.15$ \\
\hline & $\begin{array}{l}\text { Field texture } \\
\left(\mathrm{PSD}^{\mathrm{b}}\right)\end{array}$ & & $\begin{array}{l}\text { Light to medium heavy clay } \\
(38 \%, 11 \%, 51 \%)\end{array}$ & $\begin{array}{l}\text { Sandy light clay to medium heavy clay } \\
(47 \%, 12 \%, 41 \%) \text { to }(27 \%, 18 \%, 55 \%)\end{array}$ & $\begin{array}{l}\text { Medium clay } \\
(67 \%, 12 \%, 21 \%)\end{array}$ \\
\hline & Structure & & Weak & Massive to moderate & Strong \\
\hline & Stability & & Slaked and dispersed & Stable or slaked & N/A \\
\hline \multirow[t]{5}{*}{$\mathrm{C}$} & Depth $^{\mathrm{a}}$ & $0.80-1.50$ to 6.00 & $0.85-3.00$ to 6.00 & $5.10-5.95$ & Not present \\
\hline & Field texture & $\mathrm{N} / \mathrm{A}$ & Sandy clay loam & N/A & \\
\hline & $\left(\mathrm{PSD}^{\mathrm{b}}\right)$ & $(14 \%, 5 \%, 81 \%)$ & $(26 \%, 10 \%, 64 \%)$ & $\mathrm{N} / \mathrm{A}$ & \\
\hline & Structure & N/A & Grainy or massive & N/A & \\
\hline & Stability & $\mathrm{N} / \mathrm{A}$ & N/A & N/A & \\
\hline
\end{tabular}

Not present $=$ horizon absent at that location, $\mathrm{N} / \mathrm{A}=$ measurement is not available.

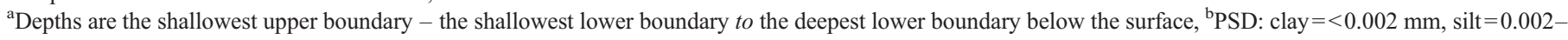
$0.02 \mathrm{~mm}$, sand $=>0.02 \mathrm{~mm}$.

include evidence of salinity scalds, with surface EC's up to $8.2 \mathrm{dS} /$ $\mathrm{m}$ (Table 3) and an abundance of plant species tolerant of waterlogging and salinity, such as Critesion marium (Sea Barley Grass) and Cynodon dactylon (Couch Grass).

\subsubsection{Morphology of the A2 horizon}

The A2 horizon warrants particular attention given the aims of this study. Our observations suggest that significant saturation occurs in the A2 horizon and the period of saturation increases down the hillslope. The colour becomes increasingly paler changing from a light yellow-brown on the upperslope to white on the lowerslope (Table 2). The abundance of redox concretions increases from $0 \%$ on the upperslope to up to $25 \%$ on the lowerslope. Also there is evidence of mottling on the midslope and lowerslope but not on the waning-midslope or upperslope. The greater evidence of saturation in the A2 horizon down the hillslope should correspond to an increase in the area contributing water by lateral flow. This suggests that SLF is 
Table 2

Description of key horizons colour, mottle and redox concretions (McDonald et al., 1990)

\begin{tabular}{|c|c|c|c|c|c|}
\hline Horizon & Property & Upperslope & Waning-midslope & Midslope & Lowerslope \\
\hline \multirow[t]{3}{*}{$\mathrm{A} 1$} & Colour $^{\mathrm{a}}$ & $\begin{array}{l}\text { Dark brown } \\
(10 \text { Y } 2 / 2)\end{array}$ & $\begin{array}{l}\text { Pale brown to yellow-brown } \\
\text { (10YR } 2 / 1,10 \text { YR } 2 / 2)\end{array}$ & Dark brown (10YR 4/2, 10YR 3/3) & $\begin{array}{l}\text { Light grey to white } \\
(10 \mathrm{YR} 7 / 2,10 \mathrm{YR} 8 / 2)\end{array}$ \\
\hline & Mottle & $0 \%$ & $0 \%$ & $0 \%$ & $\begin{array}{l}0 \text { to } 2 \% \text { distinct light } \\
\text { grey-brown (10YR } 6 / 2) \text {, }\end{array}$ \\
\hline & Concretions & None & $0 \% \mathrm{Fe}, 0 \%$ to $2 \% \mathrm{Mn}$ & $0 \% \mathrm{Fe}, 0$ to $2 \% \mathrm{Mn}$ & $2 \% \mathrm{Fe}$ and $\mathrm{Mn}$ \\
\hline \multirow[t]{3}{*}{ A2 } & Colour $^{\mathrm{a}}$ & $\begin{array}{l}\text { Light yellow-brown } \\
\text { (10YR 6/4), }\end{array}$ & $\begin{array}{l}\text { Pale brown to yellow-brown } \\
\text { (10YR } 7 / 3,10 \text { YR } 6 / 4)\end{array}$ & $\begin{array}{l}\text { Light grey to very pale brown } \\
\text { (10YR } 7 / 2 \text { to } 10 \text { YR } 7 / 4) \text {, }\end{array}$ & $\begin{array}{l}\text { Light grey to white } \\
(10 \text { YR } 7 / 2,10 \text { YR } 8 / 2)\end{array}$ \\
\hline & Mottle & $0 \%$ & $0 \%$ & $\begin{array}{l}0 \text { to } 20 \% \text { faint yellow-brown and } \\
\text { grey-brown (10YR } 5 / 6 \text { and } 10 \text { YR } 5 / 2 \text { ), }\end{array}$ & $\begin{array}{l}0 \text { to } 10 \% \text { faint brown to } \\
\text { dark grey }(10 \mathrm{YR} 5 / 3,10 \mathrm{YR} 4 / 1)\end{array}$ \\
\hline & Concretions & None & $0 \%$ to $2 \% \mathrm{Fe}$ and $\mathrm{Mn}$ & 0 to $10 \% \mathrm{Fe}$ and $\mathrm{Mn}$ & 0 to $50 \% \mathrm{Fe}, 2$ to $50 \% \mathrm{Mn}$ \\
\hline \multirow[t]{3}{*}{ B2 } & Colour $^{\mathrm{a}}$ & $\begin{array}{l}\text { Strong brown } \\
(7.5 \mathrm{YR} 4 / 6)\end{array}$ & $\begin{array}{l}\text { Yellow-brown to brown } \\
\text { (10YR 6/4, 10YR 5/3), }\end{array}$ & $\begin{array}{l}\text { Yellow-brown to grey-brown } \\
(10 \mathrm{YR} 5 / 6 \text { to } 10 \mathrm{YR} 5 / 2)\end{array}$ & $\begin{array}{l}\text { Dark grey to light grey-brown } \\
\text { (10YR 3/1, 10YR 5/3) }\end{array}$ \\
\hline & Mottle & $0 \%$ & $\begin{array}{l}10 \text { to } 20 \% \text { distinct brown to } \\
\text { yellow-brown (10YR 4/3, 10YR 5/6), }\end{array}$ & $\begin{array}{l}0 \text { to } 50 \% \text { prominent yellow-brown } \\
\text { to dark grey-brown } \\
(10 \mathrm{YR} 5 / 6 \text { to } 10 \mathrm{YR} 4 / 2)\end{array}$ & $\begin{array}{l}0 \text { to } 50 \% \text { faint to distinct dark } \\
\text { brown to dark grey-brown } \\
(10 Y R 5 / 3,2.5 Y 4 / 2)\end{array}$ \\
\hline & Concretions & None & $0 \% \mathrm{Fe}, 0 \%$ to $10 \% \mathrm{Mn}$ & 0 to $50 \% \mathrm{Fe}$ and $\mathrm{Mn}$ & 0 to $10 \% \mathrm{Fe}, 10$ to $20 \% \mathrm{Mn}$ \\
\hline \multirow[t]{3}{*}{$2 \mathrm{~A} 2$} & Colour $^{\mathrm{a}}$ & Not present & Not present & $\begin{array}{l}\text { Brown to very pale brown } \\
(10 \mathrm{YR} 4 / 3 \text { to } 10 \mathrm{YR} 7 / 3) \text {, }\end{array}$ & Brown-yellow (10 YR 6/6) \\
\hline & Mottle & & & & $\begin{array}{l}10 \% \text { faint brown-yellow } \\
(10 \text { YR } 6 / 8)\end{array}$ \\
\hline & Concretions & & & 20 to $50 \% \mathrm{Fe}$ and $\mathrm{Mn}$ & $0 \% \mathrm{Fe}$ and $\mathrm{Mn}$ \\
\hline \multirow[t]{3}{*}{$2 \mathrm{~B} 22$} & Colour $^{\mathrm{a}}$ & Not present & $\begin{array}{l}\text { Brown to strong brown } \\
(7.5 \text { YR } 3 / 4,7.5 \text { YR } 4 / 6)\end{array}$ & $\begin{array}{l}\text { Yellow-brown (10 YR 4/6) to } \\
(10 \text { YR 4/4) }\end{array}$ & Brown (10 YR 5/3) \\
\hline & Mottle & & $\begin{array}{l}2 \text { to } 50 \% \text { faint yellow-brown to } \\
\text { grey-brown (10YR 5/6,10YR 4/2), }\end{array}$ & $\begin{array}{l}10 \text { to } 50 \% \text { distinct red, yellow } \\
\text { and grey-brown } \\
(5 \text { YR } 3 / 4,10 \text { YR } 5 / 4,10 \text { YR 4/2) }\end{array}$ & $\begin{array}{l}10 \% \text { faint brown-yellow } \\
(10 \text { YR } 6 / 8)\end{array}$ \\
\hline & Concretions & & $0 \% \mathrm{Fe}, 0$ to $10 \% \mathrm{Mn}$ & 0 to $10 \% \mathrm{Fe} ; 2$ to $10 \% \mathrm{Mn}$ & $0 \%$ to $10 \% \mathrm{Fe}$ and $\mathrm{Mn}$ \\
\hline \multirow[t]{3}{*}{ 2B23 } & Colour $^{\mathrm{a}}$ & Not present & $\begin{array}{l}\text { Red-brown to ]red-yellow } \\
\text { (5YR 4/4, } 7.5 \text { YR } 6 / 6)\end{array}$ & $\begin{array}{l}\text { Strong brown to dark yellow-brown } \\
(7.5 \text { YR } 4 / 6) \text { to }(10 \text { YR } 4 / 4)\end{array}$ & Brown-yellow (10YR 6/6) \\
\hline & Mottle & & $\begin{array}{l}20 \text { to } 50 \% \text { distinct red to dark grey- } \\
\text { brown }(2.5 \mathrm{YR} 4 / 6,10 \mathrm{YR} 4 / 2) \text {, }\end{array}$ & $\begin{array}{l}50 \% \text { prominent red, brown and yellow } \\
(2.5 \text { YR } 3 / 6,7.5 \text { YR } 5 / 8,5 \text { YR } 4 / 6)\end{array}$ & $\begin{array}{l}50 \% \text { distinct light grey } \\
(10 \text { YR } 7 / 2)\end{array}$ \\
\hline & Concretions & & 0 to $5 \% \mathrm{Fe}, 5$ to $20 \% \mathrm{Mn}$ & 0 to $10 \% \mathrm{Fe}, 2$ to $10 \% \mathrm{Mn}$ & $0 \%$ to $10 \% \mathrm{Fe}$ and $\mathrm{Mn}$ \\
\hline \multirow[t]{3}{*}{$2 \mathrm{~B} 24$} & Colour $^{\mathrm{a}}$ & Not present & Not present & Not present & Brown (7.5 YR 5/4), \\
\hline & Mottle & & & & $20 \%$ distinct Brown (10 YR 5/3) \\
\hline & Concretions & & & & $10 \% \mathrm{Fe} ; 2 \% \mathrm{Mn}$ \\
\hline \multirow[t]{3}{*}{ 2B25 } & Colour $^{\mathrm{a}}$ & Not present & $\begin{array}{l}\text { Yellow-brown to grey } \\
(10 \text { YR } 5 / 4,5 Y 7 / 2)\end{array}$ & Yellow-brown (10 YR 6/4) & Light yellow-brown (10 YR 6/4) \\
\hline & Mottle & & $\begin{array}{l}20 \text { to } 50 \% \text { prominent yellow, } \\
\text { brown and olive } \\
(10 \mathrm{YR} 7 / 8,7.5 \mathrm{YR} 5 / 6,2.5 \mathrm{Y} 5 / 4)\end{array}$ & $\begin{array}{l}10 \% \text { to } 50 \% \text { distinct to } \\
\text { prominent brown-yellow and } \\
\text { white }(10 \mathrm{YR} 6 / 8,10 \mathrm{YR} 8 / 2)\end{array}$ & $\begin{array}{l}50 \% \text { prominent light grey } \\
(10 \text { YR } 7 / 1)\end{array}$ \\
\hline & Concretions & & $0 \% \mathrm{Fe}, 0$ to $2 \% \mathrm{Mn}$ & 0 to $20 \% \mathrm{Fe}$ and $\mathrm{Mn}$ & $0 \% \mathrm{Fe}$ and $\mathrm{Mn}$ \\
\hline \multirow[t]{3}{*}{$\mathrm{C}$} & Colour $^{\mathrm{a}}$ & N/A & $\begin{array}{l}\text { Olive-brown to brown-yellow } \\
(2.5 \mathrm{Y} 5 / 4 \text { to } 10 \mathrm{YR} 6 / 6)\end{array}$ & N/A & Not present \\
\hline & Mottle & N/A & $0 \%$ & N/A & \\
\hline & Concretions & N/A & N/A & N/A & \\
\hline
\end{tabular}

Not present=horizon absent at that location, N/A=measurement is not available.

${ }^{\mathrm{a}}$ Colours are for moist soil, except for dry A2 horizon colours.

occurring from one hillslope zone to the next and is periodically significant in the A2 horizon at this site. The increase in clay and silt content in the A2 horizon (Table 1) down the hillslope also indicates that SLF is occurring, concentrating the finer material on the lowerslope.

Soil colour can be used to indicate the period of soil saturation, reflecting the mineral composition of the $\mathrm{Fe}$ present. In a soil that is rarely saturated, implying that it is well drained, the $\mathrm{Fe}$ can exist as hematite $\left(\mathrm{Fe}_{2} \mathrm{O}_{3}\right)$ and gives the soils a red colour. While in poorer drained soils that experience periods of saturation with water, the $\mathrm{Fe}$ tends to exist as goethite $(\mathrm{FeOOH})$ and gives the soil a yellow pigment. The sequence of soil colours from red - brown - yellow - grey, correspond to an increase in the degree of saturation. Grey colours are created when soil is subject to extended periods of saturation with water and the $\mathrm{Fe}$ is reduced. At the field site evidence indicates that the period of saturation in the B2 horizon increases down the hillslope, implying that the drainage decreases. The colour changes from strong brown on the upperslope to dark grey on the lowerslope, and the abundance of mottling and redox concretions also increases (Table 2). In general this agrees with the patterns in the CEC of the clay fraction. The A2 horizon is generally more weathered (i.e. small CEC) compared to the horizon below, with this difference tending to increase down the hillslope (Table 3). The exception was in the midslope where the CEC is similar between the $\mathrm{A} 2$ and $\mathrm{B} 2$ horizons. This suggests that the degree 
Table 3

Description of the chemical properties $\left(\mathrm{pH},{ }^{\mathrm{a}} \mathrm{EC}=\right.$ electrical conductivity, ${ }^{\mathrm{b}} \mathrm{ESP}=$ exchangeable sodium percent, ${ }^{\mathrm{c}} \mathrm{CEC}=$ cation exchange capacity as $\operatorname{cmol}(+) / \mathrm{kg}$ of clay) for the key soil horizons

\begin{tabular}{|c|c|c|c|c|c|}
\hline Horizon & Property & Upperslope & $\begin{array}{l}\text { Waning- } \\
\text { midslope }\end{array}$ & Midslope & Lowerslope \\
\hline \multirow[t]{4}{*}{ A1 } & $\mathrm{pH}$ & $6.7-7.0$ & $6.2-6.6$ & $6.0-6.3$ & $5.5-6.0$ \\
\hline & $\mathrm{EC}^{\mathrm{a}}(\mathrm{dS} / \mathrm{m})$ & 0.04 & $0.01-0.007$ & 0.35 & 0.56 \\
\hline & $\mathrm{ESP}^{\mathrm{b}}(\% \mathrm{CEC})$ & 0.7 & $0.5-0.6$ & $0.9-2.3$ & 0.5 \\
\hline & $\begin{array}{l}\mathrm{CEC}^{\mathrm{c}}(\mathrm{cmol}(+) / \\
\mathrm{kg} \text { clay })\end{array}$ & 1.5 & $1.7-2.2$ & $2.6-4.0$ & 3.4 \\
\hline \multirow[t]{4}{*}{ A2 } & $\mathrm{pH}$ & $6.4-6.5$ & $6.2-7.0$ & $6.4-7.0$ & $8.5-9.0$ \\
\hline & $\mathrm{EC}^{\mathrm{a}}(\mathrm{dS} / \mathrm{m})$ & 0.03 & $\begin{array}{l}0.002- \\
0.004\end{array}$ & 0.019 & 0.03 \\
\hline & $\mathrm{ESP}^{\mathrm{b}}(\% \mathrm{CEC})$ & $1.0-1.2$ & $1.1-1.2$ & $0.8-1.0$ & 2.2 \\
\hline & $\begin{array}{l}\mathrm{CEC}^{\mathrm{c}}(\mathrm{cmol}(+) / \\
\mathrm{kg} \text { clay })\end{array}$ & $0.9-1.5$ & $1.0-1.1$ & $1.8-2.7$ & 2.0 \\
\hline \multirow[t]{4}{*}{ B2 } & $\mathrm{pH}$ & $6-6.1$ & $6.6-6.7$ & $7.0-7.9$ & $8.5-9.5$ \\
\hline & $\mathrm{EC}^{\mathrm{a}}(\mathrm{dS} / \mathrm{m})$ & 0.02 & 0.031 & 0.052 & N/A \\
\hline & $\operatorname{ESP}^{\mathrm{b}}(\%)$ & $0.4-0.6$ & $1.5-7.9$ & $0.6-2.1$ & 13.4 \\
\hline & $\begin{array}{l}\mathrm{CEC}^{\mathrm{c}}(\operatorname{cmol}(+) / \\
\mathrm{kg} \text { clay })\end{array}$ & $2.3-5.7$ & $3.6-4.1$ & $2.6-3.2$ & 16.5 \\
\hline \multirow[t]{4}{*}{$2 \mathrm{~A} 2$} & $\mathrm{pH}$ & Not present & Not present & $7.2-8.7$ & 9.0 \\
\hline & $\mathrm{EC}^{\mathrm{a}}(\mathrm{dS} / \mathrm{m})$ & & & 0.053 & N/A \\
\hline & $\mathrm{ESP}^{\mathrm{b}}(\% \mathrm{CEC})$ & & & 0.8 & 10.6 \\
\hline & $\begin{array}{l}\mathrm{CEC}^{\mathrm{C}}\left(\mathrm{cmol}^{(+)} /\right. \\
\mathrm{kg} \text { clay })\end{array}$ & & & 2.0 & 5.7 \\
\hline \multirow[t]{4}{*}{$2 \mathrm{~B} 22$} & $\mathrm{pH}$ & Not present & 7.3 & $7.4-8.0$ & 9.0 \\
\hline & $\mathrm{EC}^{\mathrm{a}}(\mathrm{dS} / \mathrm{m})$ & & $\mathrm{N} / \mathrm{A}$ & 0.052 & N/A \\
\hline & $\mathrm{ESP}^{\mathrm{b}}(\% \mathrm{CEC})$ & & $\mathrm{N} / \mathrm{A}$ & $2.3-4.2$ & $\mathrm{~N} / \mathrm{A}$ \\
\hline & $\begin{array}{l}\mathrm{CEC}^{\mathrm{c}}(\mathrm{cmol}(+) / \\
\mathrm{kg} \text { clay })\end{array}$ & & N/A & $3.0-4.5$ & N/A \\
\hline \multirow[t]{4}{*}{$2 \mathrm{~B} 23$} & $\mathrm{pH}$ & Not present & 8.6 & $6.1-8.0$ & 9.0 \\
\hline & $\mathrm{EC}^{\mathrm{a}}(\mathrm{dS} / \mathrm{m})$ & & $\begin{array}{l}0.007- \\
0.008\end{array}$ & 0.062 & 0.10 \\
\hline & $\mathrm{ESP}^{\mathrm{b}}(\% \mathrm{CEC})$ & & 15.1 & 11.8 & 11.0 \\
\hline & $\begin{array}{l}\mathrm{CEC}^{\mathrm{c}}(\operatorname{cmol}(+) / \\
\mathrm{kg} \text { clay })\end{array}$ & & 4.6 & 3.4 & 4.2 \\
\hline \multirow[t]{4}{*}{ 2B24 } & $\mathrm{pH}$ & Not present & Not present & $\begin{array}{l}\text { Not } \\
\text { present }\end{array}$ & N/A \\
\hline & $\mathrm{EC}^{\mathrm{a}}(\mathrm{dS} / \mathrm{m})$ & & & & N/A \\
\hline & $\mathrm{ESP}^{\mathrm{b}}(\% \mathrm{CEC})$ & & & & N/A \\
\hline & $\begin{array}{l}\mathrm{CEC}^{\mathrm{c}}(\operatorname{cmol}(+) / \\
\mathrm{kg} \text { clay })\end{array}$ & & & & $\mathrm{N} / \mathrm{A}$ \\
\hline \multirow[t]{4}{*}{$2 \mathrm{~B} 25$} & $\mathrm{pH}$ & Not present & $8.6-9.0$ & $6.3-6.8$ & 9.0 \\
\hline & $\mathrm{EC}^{\mathrm{a}}(\mathrm{dS} / \mathrm{m})$ & & $0.008-0.01$ & 0.043 & N/A \\
\hline & $\mathrm{ESP}^{\mathrm{b}}(\% \mathrm{CEC})$ & & 17.7 & 11.3 & 10.1 \\
\hline & $\begin{array}{l}\mathrm{CEC}^{\mathrm{c}}\left(\mathrm{cmol}^{(+)} /\right. \\
\mathrm{kg} \text { clay })\end{array}$ & & 4.5 & 1.4 & 15.0 \\
\hline \multirow[t]{4}{*}{$\mathbf{C}$} & $\mathrm{pH}$ & $7-7.3$ & $8.9-9.7$ & $6.5-7.2$ & Not present \\
\hline & $\mathrm{EC}^{\mathrm{a}}(\mathrm{dS} / \mathrm{m})$ & 0.02 & $0.007-0.01$ & 0.024 & \\
\hline & $\mathrm{ESP}^{\mathrm{b}}(\% \mathrm{CEC})$ & N/A & N/A & N/A & \\
\hline & $\begin{array}{l}\mathrm{CEC}^{\mathrm{c}}(\operatorname{cmol}(+) / \\
\mathrm{kg} \text { clay })\end{array}$ & N/A & $\mathrm{N} / \mathrm{A}$ & $\mathrm{N} / \mathrm{A}$ & \\
\hline
\end{tabular}

Not present=horizon is absent at that location, N/A=measurement is not available.

of weathering in the A2 and B2 at this location is similar and thus B2 is not impeding vertical drainage. However, given that the colour of the B2 horizon suggests it is being periodically saturated, another impeding layer below B2 is probably creating saturation in both the B2 and A2 horizons on the midslope.

The average hydraulic conductivities of both the A2 and the B2 horizons suggest that neither horizon constitutes an impediment to water movement through the profile (Table 4).
However the smallest measured hydraulic conductivity of the B2 horizon was $1 \mathrm{~mm} / \mathrm{h}$, compared to $43 \mathrm{~mm} / \mathrm{h}$ in the A2 horizon. At locations where the hydraulic conductivity of the B2 horizon is approaching $1 \mathrm{~mm} / \mathrm{h}$, vertical flow would be impeded and likely to generate SLF through the more permeable A2 horizon. Spatial variation in the saturated hydraulic conductivity of the B2 horizon and its correspondence with permeability of the A2 horizon will likely influence the distribution of SLF, as was the case in a study in the Mount Lofty Ranges, South Australia (Leaney et al., 1993). Therein lies the difficulty in averaging hydraulic conductivity measurements to represent a given area.

In summary, the likelihood of SLF through the A2 horizon increases down the hillslope. The high clay content and the colour of the B2 horizon on the lowerslope indicates that the likelihood of saturation in this horizon is high and vertical drainage to deeper horizons is impeded. The high incidence of saturation would increase the potential for SLF. As with the surface conditions, the small surface and subsurface (i.e. between the $\mathrm{A} 2$ and $\mathrm{B} 2$ horizons) topographic gradient on the lowerslope would limit the rate of SLF, thus creating periods when the excess water leads to waterlogging. Flow convergence or divergence across the hillslope can be important in the development and weathering of soil profile, and the occurrence and distribution of SLF. At this field site the major soil horizons extend across the width of the monitoring site, thus Fig. 3 is an integrated two dimensional summary of the monitored subcatchment.

\subsubsection{Buried A horizons}

The next horizon that appears to be hydrologically significant is the buried A2 horizon (2A2) identified on the midslope and lowerslope (Fig. 3). Most notable on the midslope, this horizon has been subject to substantial saturation and leaching given its pale colour and large concentration of redox concretions (Table 2 ). Thus, it is potentially a lateral flow path at this site.

\subsubsection{Buried B horizons}

Based upon the soil colour, mottle colour and abundance, and the abundance of redox concretions the buried $\mathrm{B}$ horizons (2B22, 2B23, 2B24 and 2B25) appear subject to periodic saturation, the duration of the saturation increases both with horizon depth and distance down the hillslope. The horizon colours changed from brown and yellow-brown in the $2 \mathrm{~B} 22$ horizon to yellow-brown and grey in the 2B25 horizon (Table 2). Mottle colours indicative of long periods of saturation such as olive, white and light grey were evident in the 2B25 horizon, compared to red and yellow-brown mottles in the 2B22 horizons and could not be simply attributed to differences in parent material (e.g. as indicated by texture) (Tables 1 and 2). The mottle contrast also increased with depth. This, as well as the large ESP at depth (Table 3), may be explained by a bedrock watertable that saturates up through the buried soils.

The zone of fluctuation for the bedrock watertable could be as high as the $2 \mathrm{~B} 22$ horizon, given that mottling and redox concretion occurs in that horizon (Table 2). However, the mottling and redox concretion trends in the buried $\mathrm{B}$ horizons on the lowerslope showed a confusing pattern. It appears that the 2B23 
horizon had a medium to low degree of periodic saturation because there was limited Fe concretion but there was mottling. The 2B22 and 2B24 horizons were subject to greater periods of saturation and less fluctuation, as indicated by Fe concretions and less mottling than in the 2B23 horizon, and again it was not obvious that the differences were due to variation in parent material. It is not clear how a horizon that experienced a shorter duration of saturation (2B23) could be between horizons that have longer periods of saturation (2B22 and 2B24), but it is clear that the buried soils on the lowerslope experienced a significant degree of saturation that may have extended up as far as the 2B22 horizon.

Redox concretions were present in all buried horizons except the 2B25 horizon on the lowerslope (Table 2). The soil colour at this location (light yellow-brown with 50\% light grey mottle) indicates that prolonged saturation has occurred, so it is probable that no redox concretions were present due to the Fe and Mn being completely leached out of the horizon. However, care must be taken when interpreting redox properties because other mechanisms can influence the reduction and leaching of $\mathrm{Fe}$ as discussed below.

\subsubsection{Summary and conceptual model}

The conceptual model of water flow paths based upon the two dimensional soil stratigraphy of the field site is presented with arrows in Fig. 3. Four lateral flow paths were identified down the hillslope.

The first was surface runoff, which would be the major lateral component off the steep rocky upperslope. At the breakof-slope, some water would remain as surface runoff and move to the valley bottom, but the rapid change in gradient would promote infiltration. Poaching on the surface from cattle on the midslope down to the lowerslope is likely to reflect periodic saturation of the A1 and A2 horizons due to impeded drainage, indicating the role of the B2 horizon in initiating saturation excess surface runoff downslope. The rate of surface flow off the lowerslope would likely be small, unless it was saturated, due to the low topographic gradient (4\%).

Of the water that does infiltrate into the upperslope, a small percentage may move laterally through the A2 horizon, but SLF does not appear to become significant until the waning-midslope. There, saturated conditions appear to occur periodically, with water moving laterally through the A2 horizon to the bottom of the hillslope. This implies that the gradient of $10 \%$ to $15 \%$ in this location on the hillslope (waning-midslope to midslope) is sufficient to move soil water laterally. The increase in clay and silt content in the A2 horizon indicates that lateral flow may be quite extensive in this horizon. SLF through the A2 horizon is restricted on the lowerslope by the small topographic gradient and vertical flow is impeded by the B2 horizon, which results in surface waterlogging and saturation excess runoff.

It is not clear whether the dominant source of water for lateral flow in the 2A2 horizon is lateral flow from the waningmidslope or vertical drainage through the B2 horizon. But with the saturated hydraulic conductivity of the B2 horizon being higher than expected rainfall intensity in some locations on the midslope, it is likely that some water is contributed vertically.

The shallow sandy soils in the upperslope are an important intake area for the water that supplies the bedrock flow path. The majority of the water moves through the B2 horizon and into the $\mathrm{C}$ horizon on the upperslope and is likely to move laterally on top of and through the saprolite and over the solid bedrock. The apparent dyke in the bedrock that appears between the upperslope and the waning-midslope does not inhibit lateral flow, as the strong brown soil at this depth on the upperslope indicates that the soil is aerated. It is likely that the sandy texture of the soil and fractures within the granite bedrock enable reasonable drainage. The bedrock flow accumulates on the waning-midslope and midslope to generate a rising watertable, which fluctuates seasonally. On the lowerslope, the lateral flow on the bedrock accumulates periodically saturating up through to the $2 \mathrm{~B} 22$ horizon.

\subsection{Measured hillslope hydrological response}

The measured hydrological response was limited by the drought conditions that persisted throughout the monitoring period from August 2001 to October 2003. During the monitoring period the total rainfall was $1440 \mathrm{~mm}$, with the rainfall for the 2002 calendar year being $539 \mathrm{~mm}, 156 \mathrm{~mm}$ below the longterm average in this region of the Billabong Creek catchment (Queensland Department of Natural Resources, 2003).

Analysis of the hydrological data of the study area indicates that up to five lateral flow paths exist at this field site. They are

Table 4

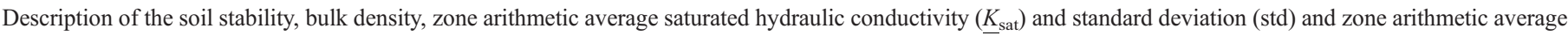
unsaturated hydraulic conductivity $\left(K_{\text {unsat }}\right)$ and standard deviation $(\mathrm{std})$

\begin{tabular}{|c|c|c|c|c|c|}
\hline Horizon & Property & Upperslope & Waning-midslope $^{\mathrm{a}}$ & Midslope & Lowerslope \\
\hline \multirow[t]{5}{*}{ A2 } & $\mathrm{BD}\left(\mathrm{g} / \mathrm{cm}^{3}\right)$ & 1.58 & (pasture) 1.55 (tree belt) 1.60 & $1.58-1.62$ & $\mathrm{~N} / \mathrm{A}$ \\
\hline & $K_{\text {sat }}$ av. $[\mathrm{std}](\mathrm{mm} / \mathrm{h})$ & $\{\mathrm{sm}\} 443[96]$ & (pasture) $\{\mathrm{sm}\} 894[692]$ & $\{\mathrm{sm}\} 864[720]$ & N/A \\
\hline & & & (tree belt) $\{\mathrm{sm}\} 864[720]$ & $\{\lg \} 456[513]$ & \\
\hline & $K_{\text {unsat }}$ av. [std] $(\mathrm{mm} / \mathrm{h})$ & $\{\mathrm{sm}\} 33[4]$ & (pasture) $\{\mathrm{sm}\} 32[16]$ & $\{\mathrm{sm}\} 24[8]$ & N/A \\
\hline & & & (tree belt) $\{\mathrm{sm}\} 14[7]$ & $\{\lg \} 139[91]$ & \\
\hline \multirow[t]{3}{*}{ B2 } & $\mathrm{BD}\left(\mathrm{g} / \mathrm{cm}^{3}\right)$ & N/A & (pasture) 1.58 & 1.71 & N/A \\
\hline & $K_{\text {sat }}$ av. $[\mathrm{std}](\mathrm{mm} / \mathrm{h})$ & $\mathrm{N} / \mathrm{A}$ & N/A & $\{\lg \} 686[844]$ & N/A \\
\hline & $K_{\text {unsat }}$ av. [std] $(\mathrm{mm} / \mathrm{h})$ & $\mathrm{N} / \mathrm{A}$ & $\mathrm{N} / \mathrm{A}$ & $\{\lg \} 142[134]$ & N/A \\
\hline
\end{tabular}

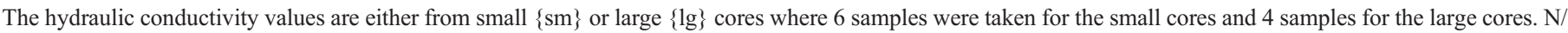
$\mathrm{A}=$ measurement is not available. Only the A2 and B2 horizons are shown because no measurements are available for the other horizons.

${ }^{a}$ for the waning-midslope a measurement may be under the pasture, or in the tree belt. 
surface runoff, SLF through the A2 horizon, flow through the 2A2 horizon, on top of the bedrock, and through a preferential flow path at approximately a $6 \mathrm{~m}$ depth. The paths are not mutually exclusive, and water is likely to move vertically between them. Some paths become more connected when the hillslope is wetter, while others are more permanent and persist throughout long dry periods.

Surface runoff occurred as both infiltration excess and saturation excess flow. During a summer storm (December 6, 2001) surface runoff was recorded at the field site (Table 5) when the rainfall intensity was high, peaking at $72 \mathrm{~mm} / \mathrm{h}$ but the antecedent water content was low (initial volumetric water content $\theta_{\mathrm{i}}=15.6 \%$ ). For this soil the drained upper limit (field capacity) is $28.4 \%(\mathrm{v} / \mathrm{v})$, and the lower limit (wilting point) is $14.4 \%(\mathrm{v} / \mathrm{v})$. This flow event is indicative of infiltration excess runoff. In other rainfall events during winter, such as on the August 24, 2003 the peak rainfall intensity was small $(12 \mathrm{~mm} / \mathrm{h})$ but the antecedent water content was greater than the drained upper limit $\left(\theta_{\mathrm{i}}=31.6 \%\right)$ and piezometers showed saturation in the A2 horizon. The surface runoff that occurred under these conditions is through the saturation excess mechanism.

SLF occurred as both short-lived bypass flow in dry antecedent conditions, and as more continuous flow in wet periods. SLF was recorded in the same summer storm on December 6, 2001. The most likely explanation, considering the dry soil conditions, is that it was preferential, bypass flow through macropores, as has been reported by Johnston (1987a,b).

When the antecedent water content and volume of event rainfall increased (Table 5), saturation response in the shallow piezometers became similar. This is illustrated in Figs. 4 and 5, which show the response in the shallow piezometers at locations 5

Table 5

Summary statistics for surface runoff, SLF through the A2 horizon and the antecedent volumetric water content $\theta_{\mathrm{i}}$ (in \%) for selected rainfall-runoff events

\begin{tabular}{|c|c|c|c|c|c|c|c|}
\hline Date & $\begin{array}{l}\text { Rainfall } \\
\text { depth } \\
(\mathrm{mm})\end{array}$ & $\begin{array}{l}\text { Runoff } \\
\text { volume }(L)\end{array}$ & $\begin{array}{l}\text { SLF } \\
\text { volume }(L)\end{array}$ & $\begin{array}{l}\text { Peak } \\
\text { rainfall } \\
\text { intensity } \\
(\mathrm{mm} / \mathrm{h})\end{array}$ & $\begin{array}{l}\text { Peak } \\
\text { runoff } \\
(L / \mathrm{h})\end{array}$ & $\begin{array}{l}\text { Peak } \\
\text { SLF } \\
(L / h)\end{array}$ & $\begin{array}{l}\Theta_{\mathrm{i}} \\
(\%)\end{array}$ \\
\hline
\end{tabular}

\begin{tabular}{ccrrrrrr}
\hline $\begin{array}{c}11 / 10 / \\
2001\end{array}$ & 26.6 & $820(0.10)$ & $3066(0.39)$ & 20.0 & 1960 & 2997 & 22.4 \\
$24 / 10 /$ & 29.6 & $964(0.11)$ & $2644(0.30)$ & 30.0 & 3170 & 4359 & 24.0 \\
2001 & & & & & & & \\
$6 / 12 /$ & 16 & $2448(0.52)$ & $358(0.08)$ & 72.0 & 12,000 & 1940 & 15.6 \\
2001 & & & & & & & \\
$5 / 7 /$ & 32.6 & $783(0.08)$ & $2118(0.22)$ & 20.0 & 2260 & 2704 & 25.6 \\
2002 & & & & & & & \\
$6 / 7 /$ & 15.4 & $309(0.07)$ & $1859(0.41)$ & 24.0 & 1440 & 4322 & 28.8 \\
2002 & & & & & & & \\
$13 / 8 /$ & 64.4 & $37,908(1.99)$ & $7090(0.37)$ & 44.0 & 52,100 & 3578 & 26.0 \\
2003 & & & & & & & \\
$24 / 8 /$ & 36.8 & $11,389(1.05)$ & $8795(0.81)$ & 10.0 & 8160 & 2737 & 31.6 \\
2003 & & & & & & & \\
$(\mathrm{M})$ & & & & & & & \\
$24 / 8 /$ & 56.6 & $11,578(0.69)$ & $14,354(0.86)$ & 12.0 & 8160 & 2737 & 31.6 \\
2003 & & & & & & & \\
$(\mathrm{~W})$ & & & & & & & \\
\hline
\end{tabular}

Runoff and SLF are presented as a volume in litres, and then in brackets as the percentage of the rainfall. $(\mathrm{M})=$ main runoff event, $(\mathrm{W})=$ whole runoff event until SLF ceased.

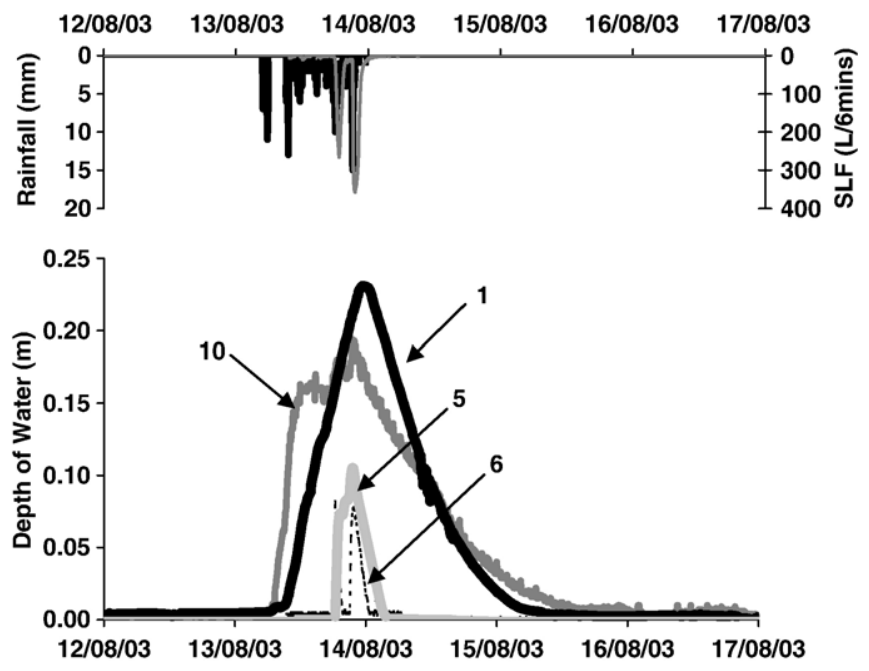

Fig. 4. Depth of saturation from the bottom of piezometers measuring water in the A2 horizon at locations 1, 5, 6, 10 shown in Fig. 2b. SLF (grey line) and rainfall (black line) are shown in the top plot.

and 6. Both showed peaks that coincided on August 24, whereas on August 13, the piezometer at location 6 had more peaks than at location 5. A likely explanation for these trends is variations in the subsurface topography and hydraulic conductivity of the B2 horizon, which controls the flow and accumulation of water. The results indicate that the perched watertable was becoming more connected when the hillslope was wetter, which would explain the increase in relative volume of SLF (Table 5) because the contributing area for flow would be greater.

The total extent of contributing area for the measured SLF and surface runoff may have extended as far as $300 \mathrm{~m}$ upslope of the troughs when the hillslope was saturated. During the runoff event on August 24, 2003 (Fig. 6) peaks in surface runoff and SLF were recorded when there was no rainfall measured in the middle rain gauge or the meteorological rain gauge, the nearest gauges to the collection equipment. However, rainfall occurred on the top of the hillslope that corresponds to the

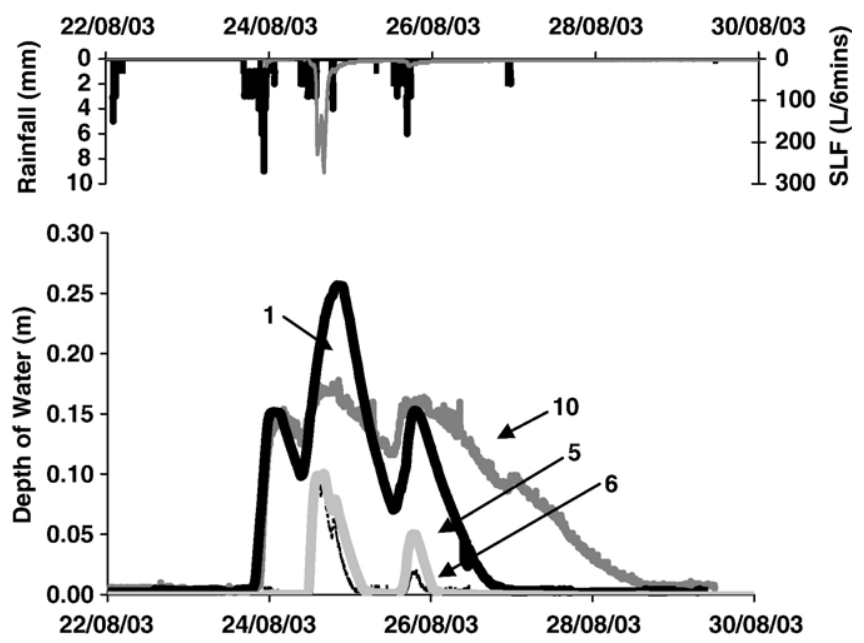

Fig. 5. Depth of saturation from the bottom of piezometers measuring water in the A2 horizon at locations 1, 5, 6, 10 shown in Fig. 2b. SLF (grey line) and rainfall (black line) are shown in the top plot. 

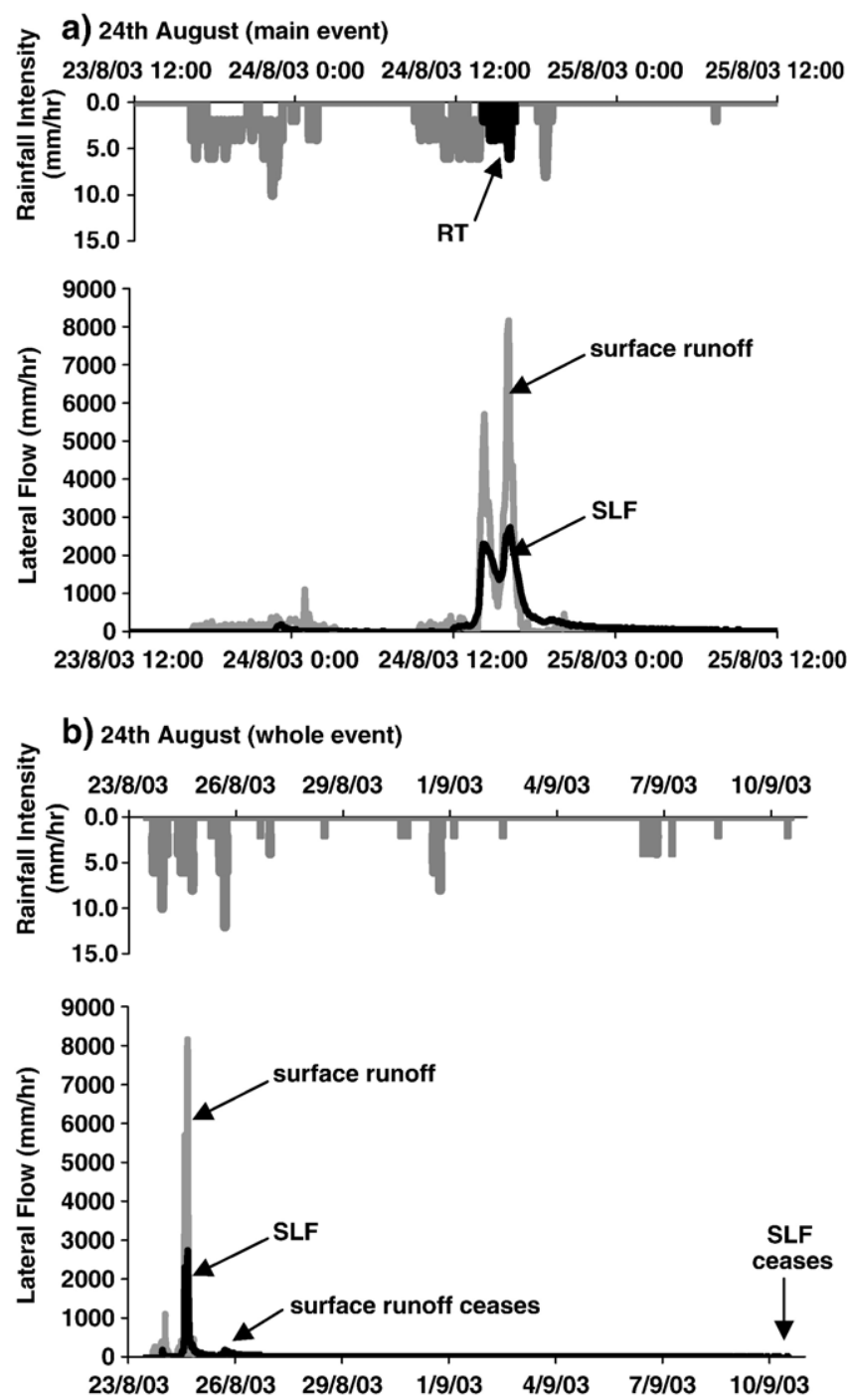

Fig. 6. Hydrographs showing surface runoff and SLF for events on (a) August 24, 2003 the main runoff period, and (b) August 24, 2003 until the SLF ceases. Rainfall from the meteorological gauge is plotted with a short period from the top gauge (RT) added.

period of observed runoff. This indicates that the water source for both surface and SLF may be from as far as the upperslope. The occurrence of rainfall at the meteorological station earlier that day might have partly filled the soil profile on the midslope, making it more responsive to lateral flow from the rainfall on the hilltop.

Saturation occurred in the $2 \mathrm{~A} 2$ horizon on August 24, 2003, when the hillslope was in its wettest state during the monitoring period. It was only recorded in the midslope zone (location 1 and 2 in Fig. 2b). Soil water content trends indicated that SLF occurred in the 2A2 horizon (Ticehurst, 2004) and showed that SLF occurs in the 2A2 horizon. The soil water content also shows that there was no saturation above the bedrock below the $2 \mathrm{~A} 2$ horizon on the midslope (i.e. at location 1 Fig. $2 \mathrm{~b}$ ) so it can be assumed that the $2 \mathrm{~A} 2$ horizon was saturated preferentially from the surface down, with possible additional lateral run-on from the upperslope.
Watertables on top of the bedrock were not acting as a single connected unit under the rainfall conditions of the monitoring period. More permanent saturation was recorded in the midslope and lowerslope zones, with the exception of locations 1 and 8 in Fig. $2 b$, but it was rarely if ever measured in the waning-midslope or the upperslope.

A bedrock watertable existed at the bottom of the study area due to a catchment-wide accumulation of water. Other related research (Cresswell, 2003) identified a bedrock constriction to lateral flow in the catchment near the bottom of the study area, and data from this study also support that model. Fig. 7 shows the Australian Height Datum (AHD) of the surface of the bedrock watertable at location 4 on the midslope and at locations 9 and 10 on the lowerslope (Fig. 2b). Each piezometer is plotted on a separate $y$-axis with a different scale to show the watertable fluctuation more clearly. The similarity in the watertable trends at locations 9 and 10 until June 2002 suggests that they are measuring the same watertable, and there is a connected water flow path between them. Fig. 8 shows the watertable depth for bedrock piezometers at locations 4 and 10 . The height at the start of the plot is set to $0 \mathrm{~m}$ for each piezometer, and subsequent water height data are adjusted relative to the starting value. The slow and subtle response after rainfall in September 2002, in the bedrock piezometer at location 10 is distinctly different to the response at location 4 . This response at location 10 is consistent with a catchment wide accumulation of water.

Another explanation is warranted for the patterns in piezometer 4. It is believed that a preferential flow path existed in sandy material on the midslope at about a $6 \mathrm{~m}$ depth, and that its
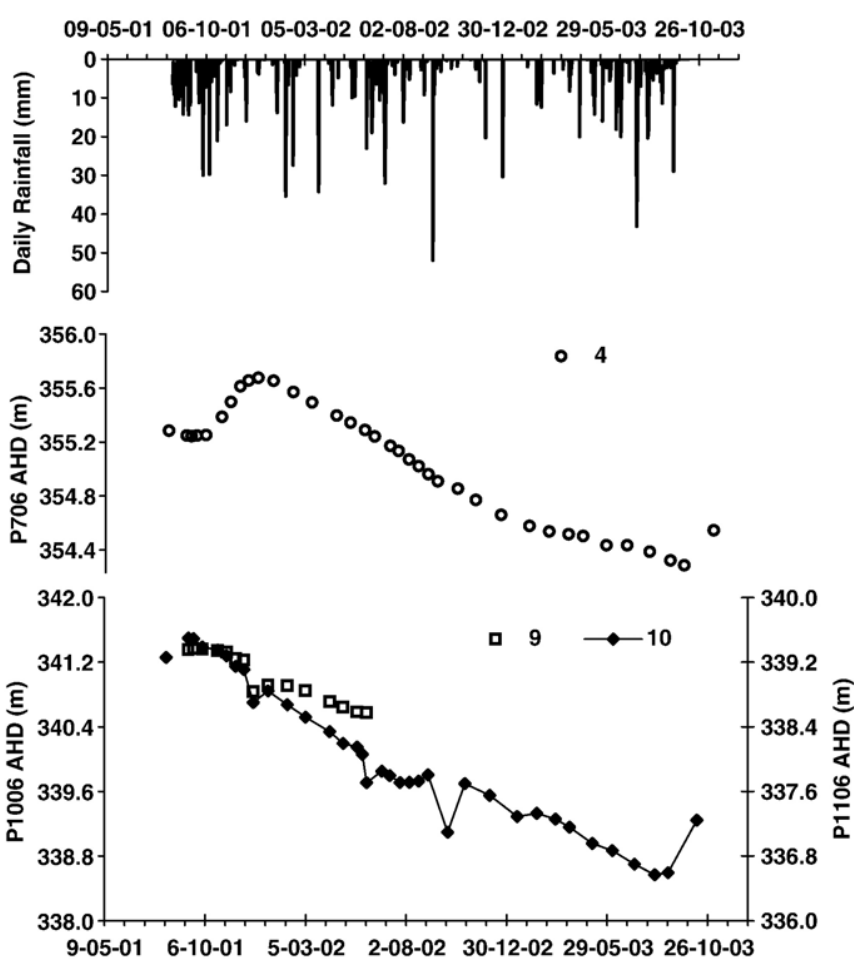

Fig. 7. Manual measurement of watertable heights in $6 \mathrm{~m}$ piezometers at locations 4, 9 and 10 (Fig. 2b), with daily rainfall for the whole sampling period. The $y$-axis scale is the Australian Height Datum (AHD) in meters, and each piezometer is plotted against a different $y$-axis. 


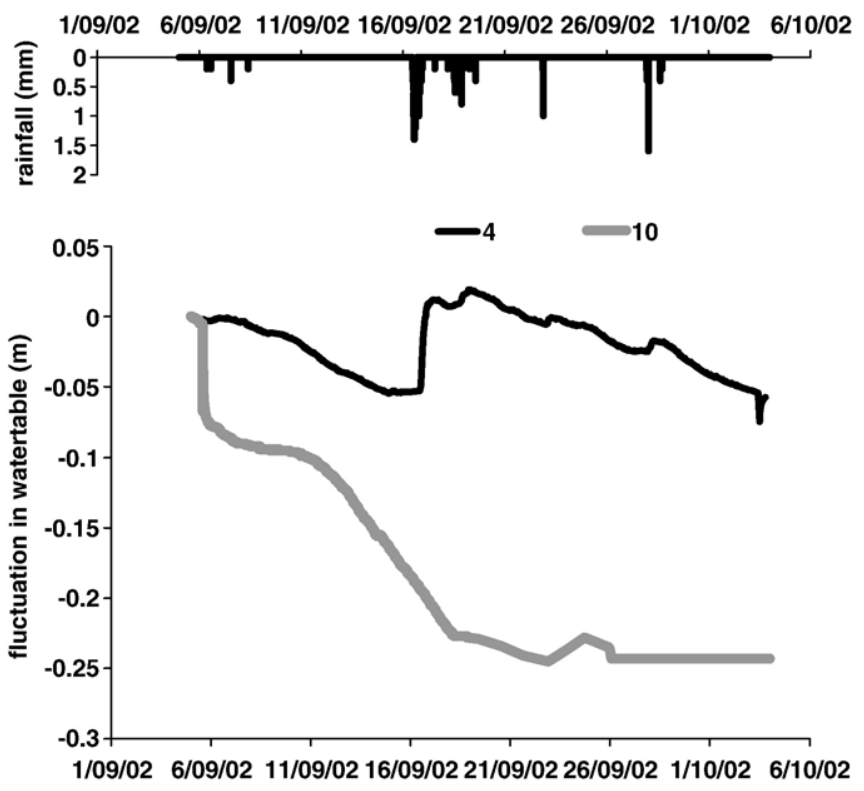

Fig. 8. 6-minute relative watertable height data from piezometers at $6 \mathrm{~m}$ depth at locations 4 and 10 (Fig. 2b) for September 2002.

main water source was rainfall infiltrating through fractures within the granite bedrock on the upperslope. The rainfall was rapidly transmitted into the bedrock aquifer and then moved laterally down the hillslope. The watertable at location 4 (Fig. 8) responded to rainfall approximately $18 \mathrm{~h}$ after the event. The reaction time does not increase as the watertable height progressively drops throughout the monitoring period; this suggests that the water flowing to that piezometer is not moving vertically but laterally from upslope. As there was no other evidence of this preferential flow path, its extent and significance on the hillslope hydrological response is likely to be minimal under the rainfall conditions of the monitoring period.

\subsection{Discussion}

In general the proposed hydrological model based solely on the soil and topographic properties of the field site gave a good approximation of the observed hydrological behaviour of the hillslope. Following a detailed study of the soil properties in context of the site geomorphological history and validation of plausible water sources for flow, four lateral flow paths were proposed: surface runoff, SLF through the A2 horizon, flow through the 2A2 horizon and deeper bedrock flow down to the lowerslope. Hydrological measurements found that these paths did exist, and also implied that an additional preferential flow path occurs on the midslope, represented by a white arrow in Fig. 3.

Anecdotal evidence, such as the presence of plant species adapted to waterlogging, sheet erosion and soil poaching, when obviously consistent with site characteristics such as surface gradient and rock outcrops, are useful in estimating the occurrence of surface runoff or saturation. Zones of concentrated infiltration can also be identified by the A horizon soil properties.

One of the most useful indicators of lateral flow at this field site was the colour of soil horizons. For example the duration of saturation increased down the hillslope in the pale A2 horizons

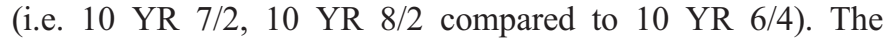
increase in the occurrence of saturation down the hillslope measured in the piezometers corresponded to the increase in the redox alteration and bleaching in the A2 horizon. Similarly the colour and concentration of redox concretions of the 2A2 horizon reflected the degree to which it became saturated when the hillslope became wet.

The soil interpretation indicated that flow through the A2 horizon connected the upperslope to the lowerslope, which proved to be the case only when the hillslope soil water content was close to the drainage upper limit. More localised lateral flow occurred in drier conditions. Soil morphology is a reflection of the dominant hydrological processes that occur at a location in this case the features of the A2 horizon were formed over many years when the rainfall was closer to the long-term average compared to during this observation period. In a year with average rainfall it is likely that the saturation and SLF in the A2 horizon would be more continuous and better reflect the soil morphology at the field site. Care must be taken when interpreting soil morphology as there may be a lag between the current hydrological conditions and the soil features reflecting it, as found by Cox et al. (1996).

The presence of mottles and Fe and Mn concretions were a good indicator of periodic saturation, and generally an increase in their abundance and size corresponded to an increase in the period of saturation. However, on the lowerslope there was a complicated pattern with variable abundances of Fe and Mn concretions and mottling, and the specific interpretation for each soil horizon did not form a physically logical picture. Care must be taken when explicitly interpreting these features because the abundance of redox alterations can reflect the period of saturation (Crown and Hoffman, 1970; Simonson and Boersma, 1972; Khan and Fenton, 1994), but the reduction of Fe, for example, can also be affected by the presence of organic matter (Vepraskas, 1992) and humic material (Duchaufour, 1982; Novak, 1994). Mottling and redox alteration are valuable for a general interpretation, but like other soil properties should not be considered to easily provide a detailed hydrological interpretation.

Relic features from past climatic and topographic environments can create uncertainty when using soil morphology to predict hydrological response (Vepraskas, 1992) and hence morphological features should not be used in isolation as an indicator of water flow (Daniels et al., 1987). The risks of misinterpreting hydrological process can be minimised by combining morphological knowledge with other lines of evidence such as analysis of landscape position (Khan and Fenton, 1994), and identifying major changes in the soil profile development.

In the region of the field site aeolian deposition has been significant throughout periods within the last 1 million years (McKenzie et al., 2004). Since then major land clearing in the Billabong Creek catchment occurred in the late 1880's and it is likely that the land slumping that is apparent at the field site has occurred following this major clearing event. The apparent extent of the A2 horizon over the existing landform suggests that the current landscape of the field site has been stable for a significant period of time, which increases the certainty that the soil features reflect contemporary hydrological processes. 
Another option to reduce the risk in soil morphology interpretation is to study the soil morphology within the context of the hillslope, or landscape, to assist in identifying feasible water sources for potentially transmitting horizons. This approach is similar to the structural approach described by Brouwer and Fitzpatrick (2002), which classifies major soil features throughout a landscape and uses them to distinguish between similar soils. In this study a two dimensional representation of the major soil horizons across the field site was developed (Fig. 3). By visualising the extent of the horizons down the hillslope it was possible to interpret the soil morphology for horizons that appeared to transmit water, and then to validate whether these layers are likely to have current access to a source of water. The near surface horizons, such as the A2, are very likely to source water from the direct infiltration of rainfall. The deeper horizons are more difficult to assign a water supply, but at this site, the fractured nature of the granite bedrock and the shallow soil depths on the upperslope suggest that there could be rapid water infiltration into the bedrock and deeper horizons, which is then transmitted down the hillslope at depth.

Consideration of major geomorphological events at the site, developing a soil morphological catena of the hillslope, and validating that there is a potential source of water for the horizons that appear to be transmitting water have each increased confidence that the observed soil morphology gives a good representation of current hydrological conditions. This was subsequently confirmed by hydrological measurements at the site, verifying that soil morphology was of assistance in identifying key soil horizons that were conducting water laterally under current climatic conditions.

\subsection{Conclusions}

Soil morphology (mainly soil colour and redox alterations) was used to successfully distinguish the main areas of saturation and potential lateral flow paths down this hillslope. Patterns in soil features, such as changes in soil colour, mottling and $\mathrm{Fe}$ and Mn concretions proved useful in identifying the locations and depths where saturation and lateral flow are likely to occur. Combining soil morphological understanding with observations of other site characteristics (such as slope, rock outcrops, indicator plant species), knowledge of geomorphological history, and surface soil condition enabled rapid site assessment and conceptualisation of hillslope hydrological behaviour. Future research should include further testing of the approach at other sites. This rapid site assessment is relatively low cost and has the potential to adequately support some increase in the precision of farm management. For example, more informed management decisions can be made on locating tree plantations to use excess water and on matching sensitive crops and pastures to soil locations not prone to waterlogging.

Soil morphological information on its own cannot be expected to provide quantitative estimates of the volume of water moving as lateral flow as might be desirable for some landuse planning. However, where more quantitative site assessment is warranted then soil morphological information still has important applications. One example is in decision-key type approaches to selecting sites for tree plantations (e.g. Ticehurst, 2004). Here an objective might be to locate tree belts so that they can harvest water moving laterally from slopes above thereby increasing potential growth and production from the trees and reducing risks from waterlogging and excessive groundwater recharge on lower slopes. The site selection decision key proposed uses soil morphological observations and site characteristics as input along with rainfall data, other soil properties, and groundwater observations to predict likely opportunities for tree belts to harvest water. Other examples where soil morphological knowledge finds application is in the design and siting of hydrological monitoring equipment.

Using soil morphology to interpret the hydrology of a hillslope is attractive in that it provides an integrated reflection of the dominant hydrological conditions at a given location from sampling at one point in time, and because of its relatively low cost compared, for example, to monitoring hydrological processes through different climatic conditions. However, soil morphology can be highly variable in space so many soil samples are often required to piece together a conceptualisation of hillslope hydrological processes. Caution must be taken that the morphological features observed are reflecting the current hydrological environment and not relic conditions.

If soil morphology indicates that saturation and lateral flow has occurred then other collaborating information should be sought to improve confidence that these are contemporary processes. This should include information on the geomorphological history of the region, mapping the extent of the major soil horizons within the landscape, and validating the potential sources of water for each hydrological flow path. Farmer observations should be highly valued and used throughout development of any conceptual hydrological model. Other supporting information such as anecdotal evidence of waterlogging (e.g. indicative plant species, poaching by livestock) might increase confidence in the interpretation and piezometers could be installed for watertable monitoring if desired to further reduce uncertainty.

\section{Acknowledgements}

This research was funded by Rural Industries Research and Development Corporation, with additional funding and technical support from CSIRO Land and Water, and Centre for Research and Environmental Studies (ANU). Thanks to Andrew and Anne Hicks for allowing this study to take place on their property.

\section{References}

Anderson, M.G., Burt, T.P., 1978. The role of topography in controlling throughflow generation. Earth Surface Processes 3, 331-344.

Baker, P., Please, P., Coram, J., Dawes, W., Bond, W., Stauffacher, M., Gilfeder, M., Probert, M., Huth, N., Gayon, D., Keating, B., Moore, A., Simpson, R., Salmon, L., Stefanski, A., 2001. Assessment of Salinity Management Options for Upper Billabong Creek Catchment, NSW: Groundwater and Farming Systems Water Balance Modelling. National Land and Water Resources Audit, Bureau of Rural Science and CSIRO, Canberra.

Birkeland, P.W., 1984. The products of weathering. In Soil and Geomorphology. Oxford University Press, New York, pp. 95-114. 
Brouwer, J., Fitzpatrick, R.W., 2002. Interpretation of morphological features in salt-affected duplex soil toposequence with an altered soil water regime in western Victoria. Australia Journal of Soil Research 40, 903-926.

Clemmens, A.J., Bos, M.G., Repogle, J.A., 1984. Portable RBC flumes for furrows and Earthen Channels. Transactions of the American Society of Agricultural Engineers 27, 1016-1026.

Cox, J.W., Fritsch, E., Fitzpatrick, R.W., 1996. Interpretation of soil features produced by ancient and modern processes in degraded landscapes: VII. Water duration. Australian Journal of Soil Research 34, 803-824.

Cresswell, H.P. (Ed.), 2003. Planning for Sustainable Landuse and Catchment Health, Technical Report No. 1, Heartlands Initiative Publication HL9-03. CSIRO with the Murray-Darling Basin Commission, Australia.

Cresswell, H.P., Hamilton, G.J., 2002. Bulk density and pore space relations. In: McKenzie, N., Coughlan, K., Cresswell, H. (Eds.), Soil Physical Measurement and Interpretation for Land Evaluation. CSIRO, Collingwood, Victoria, pp. $35-58$.

Crown, P.H., Hoffman, D.W., 1970. Relationship between watertable levels and type of mottles in four Ontario gleysols. Canadian Journal of Soil Science 50, 453-455.

Daniels, R.B., Gamble, E.E., Nelson, L.A., Weaver, A., 1987. Watertables in some North Carolina soils. USDA-SCS Soil Survey Investigation Report, vol. 40. U.S. Government Print Office, Washington D.C.

Duchaufour, P., 1982. Pedology. George Allen and Urwin, London.

Dunin, F.X., Williams, J., Verburg, K., Keating, B.A., 1999. Can agricultural management emulate natural ecosystems in recharge control in south eastern Australia? Agroforestry Systems 45, 343-364.

Dunne, T., Moore, T.R., Taylor, C.H., 1975. Recognition and prediction of runoff-producing zones in humid regions. Hydrological Sciences Bulletin 3, 305-327.

Fitzpatrick, R.W., 1988. Iron compounds as indicators of pedogenic processes: Examples from the Southern Hemisphere. In: Stucki, J.W., Goodman, B.A., Schwertmann, U. (Eds.), Iron in Soils and Clay Minerals. . NATO ASI Series, Series C, Mathematical and physical sciences. D. Reidel, Dordrecht.

Fritsch, E., Fitzpatrick, R.W., 1994. Interpretation of soil features produced by ancient and modern processes in degraded landscapes: I. A new method for constructing conceptual soil-water-landscape models. Australian Journal of Soil Research 32, 889-907.

Hurley, D.G., Pantelis, G., 1985. Unsaturated and saturated flow through a thin porous layer on a hillslope. Water Resources Research 21, 821-824.

Hutka, J., 1994. Sedigraph 5100 Particle size system. A brief description and its use in soil particle size analysis work. Technical Report 9/1994. CSIRO, Division of Soils.

Isbell, R.F., 2002. The Australian Soil Classification. CSIRO Publishing, Melbourne.

Isbell, R.F., McDonald, W.S., Ashton, L.J., 1997. Concepts and Rationale of the Australian Soil Classification. CSIRO Publishing, Melbourne.

Johnston, C.D., 1987a. Distribution of environmental chloride in relation to subsurface hydrology. Journal of Hydrology 94, 67-88.

Johnston, C.D., 1987b. Preferred water flow and localised recharge in a variable regolith. Journal of Hydrology 94, 129-142.

Khan, F.A., Fenton, T.E., 1994. Saturated zones and soil morphology in a Mollisol catena of Central Iowa. Soil Science Society of America Journal 58, 1457-1464.

Leaney, F.W., Smettem, K.R.J., Chittleborough, D.J., 1993. Estimating the contribution of preferential flow to subsurface runoff from a hillslope using deuterium and chloride. Journal of Hydrology 147, 83-103.

McDonald, R.C., Isbell, R.F., Speight, J.G., Walker, J., Hopkins, M.S., 1990. Australian Soil and Land Survey: Field Handbook. CSIRO Australia, Canberra.

McIntyre, D.S., Loveday, J., 1974a. Hydraulic conductivity. In: Loveday, J. (Ed.), Methods for Analysis of Irrigated Soils. . Commonwealth Bureau of Soil Technical Communication, vol. 54. Commonwealth Agricultural Bureau, Farnham Royal, pp. 78-87.
McKenzie, N.J., Cresswell, H.P., 2002. Field sampling. In: McKenzie, N., Coughlan, K., Cresswell, H. (Eds.), Soil Physical Measurement and Interpretation for Land Evaluation. CSIRO, Collingwood, Victoria, pp. 11-34.

McKenzie, N.J., Jacquier, D.W., 1996. Procedures for field sampling and laboratory measurement of saturated and unsaturated hydraulic conductivity on large cores. CSIRO Division of Soils Divisional Report, vol. 125. CSIRO Division of Soils, Glen Osmond.

McKenzie, N.J., Green, T.W., Jacquier, D.W., 2002. Laboratory measurement of hydraulic conductivity. In: McKenzie, N., Coughlan, K., Cresswell, H. (Eds.), Soil Physical Measurement and Interpretation for Land Evaluation. CSIRO, Collingwood, Victoria, pp. 150-162.

McKenzie, N.J., Jacquier, D., Isbell, R., Brown, K., 2004. Australian Soils and Landscapes: An Illustrated Compendium. CSIRO Publishing, Collingwood.

Novak, P., 1994. A study of soil cover and transport processes in soils of waterlogged slopes. Rostlinna Vyroba 40, 97-104.

Rayment, G.E., Higginson, F.R., 1992a. Soil pH. Australian Laboratory Handbook of Soil and Water Chemical Methods. Inkata Press, Melbourne, pp. 17-23.

Rayment, G.E., Higginson, F.R., 1992b. Electrical conductivity. Australian Laboratory Handbook of Soil and Water Chemical Methods. Inkata Press, Melbourne, pp. 15-16.

Rayment, G.E., Higginson, F.R., 1992c. Ion exchange properties. Australian Laboratory Handbook of Soil and Water Chemical Methods. Inkata Press, Melbourne, pp. 137-194.

Ritsema, C.J., Oostindie, K., Stolte, J., 1996. Evaluation of vertical and lateral flow through agricultural loessial hillslopes using a two-dimensional computer simulation model. Hydrological Processes 10, 1091-1105.

Seelig, B.D., Richardson, R.L., 1994. Sodic soil toposequence related to focused water flow. Soil Science Society of America Journal 58, 156-213.

Simonson, G.H., Boersma, L., 1972. Soil morphology and watertable relations: II. Correlation between annual watertable fluctuations and profile features. Soil Science Society American Proceeding 36, 649-653.

Stace, H.C.T., Hubble, G.D., Brewer, R., Northcote, K.H., Sleeman, J.R., Mulcahy, M.J., Hallsworth, E.G., 1968. A Handbook of Australian Soils. Rellim, Adelaide.

Sumner, M.E., 1995. Sodic soils: new perspectives. In: Naidu, R., Sumner, M.E., Rengasamy, P. (Eds.), Australian Sodic Soils: Distribution, Properties and Management. CSIRO, Melbourne, pp. 1-34.

Suppiah, R., 2004. Trends in the southern oscillation phenomenon and Australian rainfall and changes in their relationship. International Journal of Climatology 24, 269-290.

Ticehurst, J.L., 2004. Hydrological analysis for the integration of tree belt plantations into Australia's agricultural systems. PhD Thesis, Centre for Resource and Environmental Management, Australian National University.

Ticehurst, J.L., Croke, B.F.W., Jakeman, A.J., 2005. Model design for the hydrology of tree belt plantations on hillslopes. Mathematics and Computers in Simulation 69, 188-212.

Varcoe, J.C.R., Chittleborough, D.J., Cox, J.W., 1999. Measurement and treatment of phosphorus and carbon subsoil movement. CSIRO Land and Water Technical Report, vol. 38/99. CSIRO, Adelaide.

Vepraskas, M.J., 1992. Redoximorphic features for identifying aquic conditions. North Carolina Agricultural Research Service. Technical Bulletin, vol. 301. December.

Walker, P.H., Chartres, C.J., Hutka, J., 1988. The effect of aeolian accessions on soil development on granitic rocks in south-eastern Australia. I. Soil morphology and particle-size distributions. Australian Journal of Soil Research 26, $1-16$.

Weyman, D.R., 1973. Measurement of downslope flow of water in a soil. Journal of Hydrology 20, 267-288.

Wysocki, D.A., Schoenberger, P.J., LaGarry, H.E., 2000. Geomorphology of soil landscapes. In: Sumner, M.E. (Ed.), Handbook of Soil Science. CRC Press, Florida, pp. E5-E39. E1. 